Review

\title{
Brain NMDA Receptors in Schizophrenia and Depression
}

\author{
Albert Adell 1,2 (D) \\ 1 Institute of Biomedicine and Biotechnology of Cantabria, IBBTEC (CSIC-University of Cantabria), \\ Calle Albert Einstein 22 (PCTCAN), 39011 Santander, Spain; albert.adell@csic.es or albert.adell@unican.es \\ 2 Biomedical Research Networking Center for Mental Health (CIBERSAM), 39011 Santander, Spain
}

Received: 3 June 2020; Accepted: 21 June 2020; Published: 23 June 2020

\begin{abstract}
N-methyl-D-aspartate (NMDA) receptor antagonists such as phencyclidine (PCP), dizocilpine (MK-801) and ketamine have long been considered a model of schizophrenia, both in animals and humans. However, ketamine has been recently approved for treatment-resistant depression, although with severe restrictions. Interestingly, the dosage in both conditions is similar, and positive symptoms of schizophrenia appear before antidepressant effects emerge. Here, we describe the temporal mechanisms implicated in schizophrenia-like and antidepressant-like effects of NMDA blockade in rats, and postulate that such effects may indicate that NMDA receptor antagonists induce similar mechanistic effects, and only the basal pre-drug state of the organism delimitates the overall outcome. Hence, blockade of NMDA receptors in depressive-like status can lead to amelioration or remission of symptoms, whereas healthy individuals develop psychotic symptoms and schizophrenia patients show an exacerbation of these symptoms after the administration of NMDA receptor antagonists.
\end{abstract}

Keywords: NMDA; depression; schizophrenia; subunit; glutamate; GABA

\section{Introduction}

The N-Methyl-D-aspartate (NMDA) receptor (NMDAR) is an ionotropic glutamate receptor that possesses unique characteristics. The flow of ions through the channel is blocked by $\mathrm{Mg}^{2+}$. Two different processes are necessary for activating NMDARs. First, the previous membrane depolarization removes $\mathrm{Mg}^{2+}$ ions, and second, the additional binding of co-agonists glycine and glutamate allows voltage-dependent inflow of $\mathrm{Na}^{+}$and $\mathrm{Ca}^{2+}$ ions and the outflow of $\mathrm{K}^{+}$ions. This dual gating by ligand binding and membrane depolarization makes the NMDAR receptor optimally fitted to function as a coincidence detector [1]. NMDARs are involved in several physiologic functions, and their correct operation is crucial for cellular homeostasis. Any disruption in their function is thus susceptible of resulting in the manifestation of neuropsychiatric or neurological pathologies. NMDARs are critical for neuroplasticity, i.e., the ability of the brain to adapt to novel conditions. The function of NMDARs usually declines with age, which most likely contributes to the reduced plasticity that leads to learning and memory impairment. For this reason, the impairment of learning and memory seen in a variety of different pathologies, such as Alzheimer's disease (AD), amyotrophic lateral sclerosis (ALS), Huntington's disease, Parkinson's disease (PD), schizophrenia and major depressive disorder (MDD) are associated with NMDAR malfunction. Due to the important implication of neuronal plasticity [2,3], the present review is focused on the link between NMDARs and the pathophysiology and treatment of schizophrenia and depression. Two of the most important mechanisms of synaptic plasticity that are dependent on NMDAR stimulation are long-term potentiation (LTP) and long-term depression (LTD). In LTP, a high-frequency stimulation of NMDARs produces a long-lasting increase in signal transmission between two neurons [4]. On the other hand, repetitive, low-frequency stimulation 
induces LTD by weakening specific synapses, which would counterbalance synaptic strengthening caused by LTP [5].

From a structural viewpoint, NMDARs are ionotropic glutamate receptors made up of four subunits. There are three different families of NMDAR subunits, i.e., GluN1, GluN2 and GluN3 (Figure 1). In addition, GluN2 subunits are subdivided into GluN2A, GluN2B, GluN2C and GluN2D subunits and GluN3 subunit into GluN3A and GluN3B subunits. The ion channel of the NMDAR is formed by two necessary GluN1 subunits, and either two GluN2 subunits or a combination of GluN2 and GluN3 subunits [6-8]. GluN1 subunits carry recognition sites for glycine, whereas GluN2 subunits possess recognition sites for glutamate, which determines the duration of channel opening and desensitization processes.

(A)
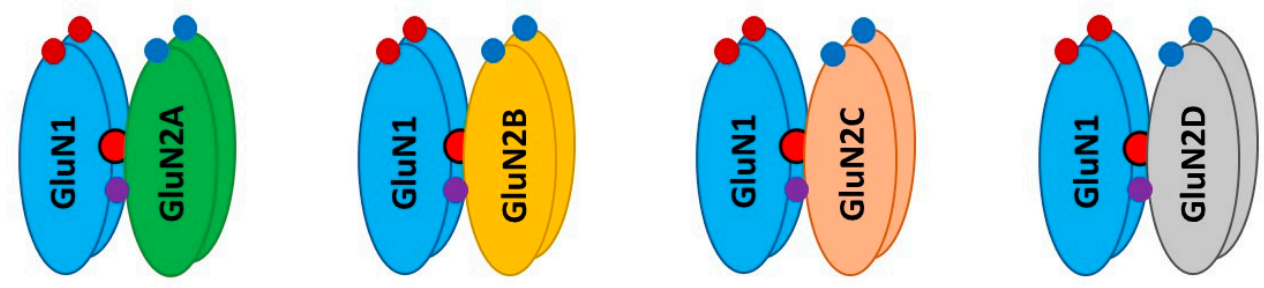

(B)
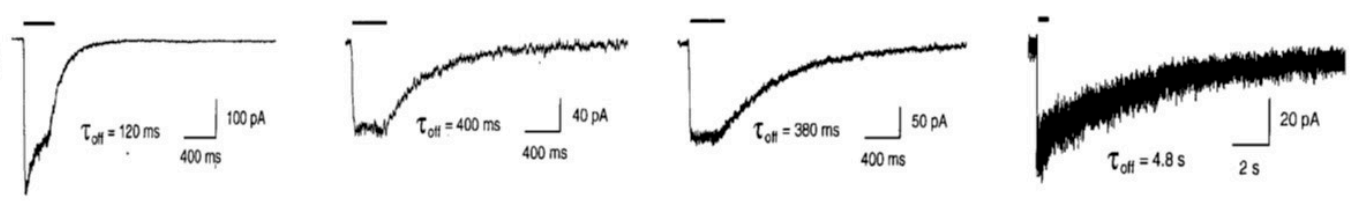

$\mathrm{Mg}^{2+}$
- Ketamine binding site

- Glycine

- Glutamate

Figure 1. Schematic illustration of the N-Methyl-D-aspartate (NMDA) receptors (NMDARs) containing GluN1 and different GluN2 subtypes (A). Lower traces (B) indicate whole-cell patch-clamp recordings of responses from brief application of glutamate ( $1 \mathrm{~ms}$ of $1 \mathrm{mM}$ glutamate) to recombinant diheteromeric NMDA receptor subtypes expressed in HEK293 cells. Averaged offset decay constant values $\left(\tau_{\text {off }}\right)$ are listed below current traces. (B) "Reprinted from Neuron, Vol 12, number 3, H. Monyer, N Burnashev, D.J. Laurie, B. Sakmann, P.H. Seeburg, Developmental and regional expression in the rat brain and functional properties of four NMDA receptors, Pages No. 529-524, Copyright (1994), with permission from Elsevier".

Overall, subunit composition of NMDARs changes along development and varies in different brain regions, which might influence the direction of synaptic plasticity. As depicted in Figure 2, the four glutamate-binding GluN2A-D subunits, in addition to the obligatory GluN1 subunit, are the most prominent subunits in the central nervous system (CNS) [9]. Cortical, hippocampal and striatal neurons in rodents are enriched in GluN2A and GluN2B subunits [8,10,11]. The GluN2D subunit is also present in the hippocampus, but only in younger rats, being undetectable in the adulthood [8]. In contrast, GluN2C subunits are practically restricted to cerebellum with low levels of expression in retrosplenial cortex and thalamus [8,12]. NMDARs are found mainly postsynaptically, although an important subset of them is also found extrasynaptically. The activation of synaptic NMDARs generally promotes synaptic and cell survival, whereas overactivation of extrasynaptic NMDARs by an excess of glutamate can be neurotoxic and induce cell death [13]. It has been reported that GluN2A subunits are predominant at the synapses, whereas GluN2B and GluN2D are localized, though not exclusively, to extrasynaptic compartment [14-17]. Thus, GluN2A-containing receptors have been reported to contribute to synaptic plasticity, whereas GluN2B-selective antagonists may possess neuroprotective properties. 
PO
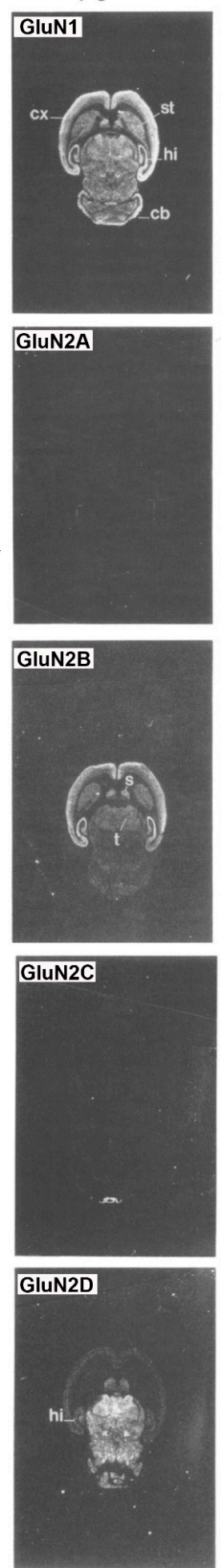

P7
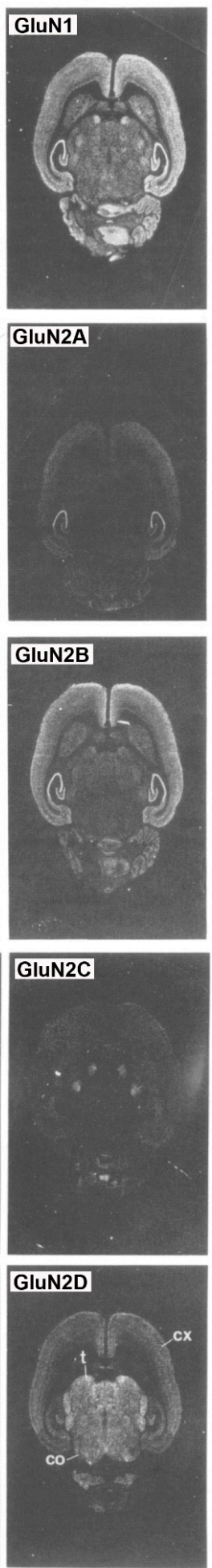

P12
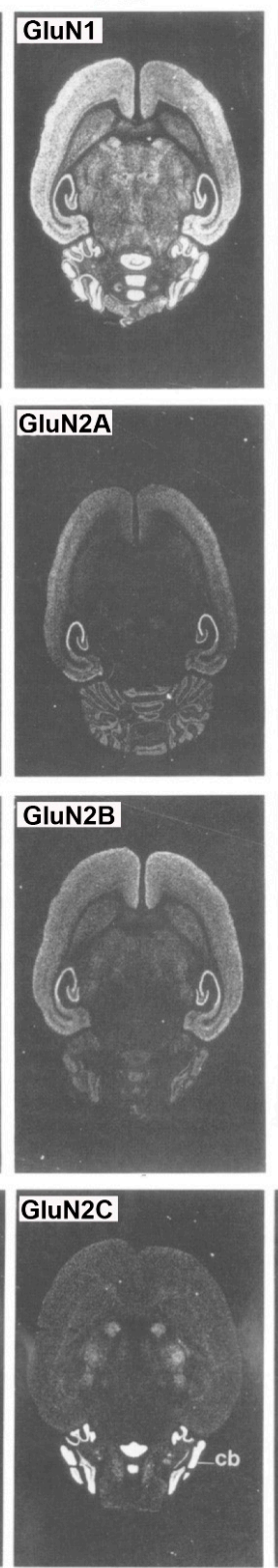

GluN2D

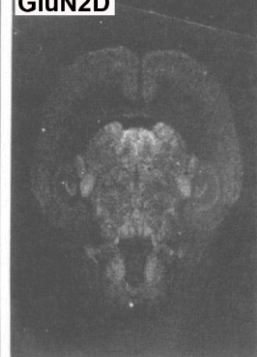

adult
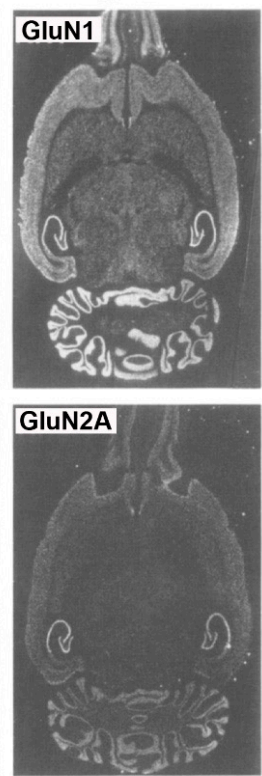

GluN2B
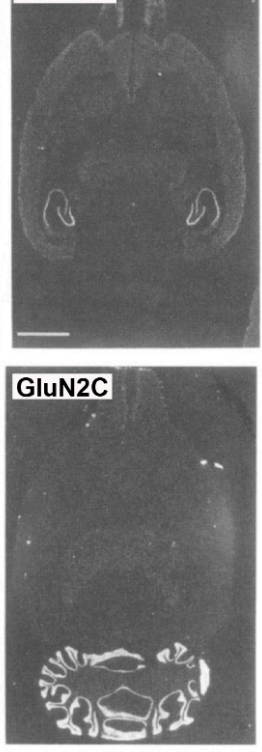

GluN2D

Figure 2. Distribution of the GluN1, GluN2A, GluN2B, GluN2C and GluN2D receptor subunit mRNAs. Postnatal developmental profiles of transcripts in horizontal rat brain sections from P0, P7, P12, and adult rats. Abbreviations: cb, cerebellum; cx, cortex; hi, hippocampus; s, septum; st, striatum; $\mathrm{t}$, thalamus. Bar, $3.4 \mathrm{~mm}$. "Reprinted from Neuron, Vol 12, number 3, H. Monyer, N Burnashev, D.J. Laurie, B. Sakmann, P.H. Seeburg, Developmental and regional expression in the rat brain and functional properties of four NMDA receptors, Pages No. 529-524, Copyright (1994), with permission from Elsevier". 
Over the last few decades, a plethora of articles have reported findings of the ability of targeting NMDARs for treating different pathologies. However, most clinical trials have failed to show significant efficacy, while exhibiting adverse effects [18,19].

\section{NMDA Receptors in Schizophrenia}

\subsection{Clinical Evidence}

The first clue of the implication of NMDARs in schizophrenia resulted from the observations that NMDAR blockers, such as phencyclidine (PCP) and ketamine, induced in healthy individuals psychotic and negative symptoms, as well as cognitive impairment, that resemble those present in schizophrenia [20-23] and exacerbated these symptoms in schizophrenic patients [24,25]. In addition, ketamine also induced a reduction of NMDA receptors in the human brain, which strongly correlated with negative symptoms [26]. More recently, neuroimaging studies have shown, for the first time, direct in vivo evidence of a reduction of NMDA receptors in the left hippocampus of medication-free schizophrenic patients [27]. Schizophrenic patients also exhibit deficits in the attention and information (cognitive and sensorial) processing measured through the prepulse inhibition (PPI) of the acoustic startle response [28-30]. PPI is known to prevent the organism from receiving an overload of information, a behavioral event altered in schizophrenia, which is reflective of abnormal functioning of the corticostriato-thalamocortical circuitry. Therefore, thalamic gating deficits would result in an excessive transfer of information to cortical structures and the subsequent cognitive deficiency. However, reductions in PPI were not observed in healthy individuals after the administration of ketamine [31], which is in sharp contrast to the effects consistently seen in rodents (see below). Another electrophysiological operation impaired in schizophrenia is mismatch negativity (MMN). MMN is an auditory event-related response in an electroencephalographic (EEG) signal, which occurs when a sequence of repetitive sounds is interrupted by an occasional "oddball" sound that differs in frequency (pitch) or duration. This sensory (auditory) information processing is also damaged, not only in schizophrenic patients [32], but also in their relatives [33,34], and it is reported to represent error in prediction. Interestingly, healthy individuals exhibit MMN after a single dose of ketamine [35]. Taking all these findings together, it is evident that not all components of the symptoms of schizophrenia in human beings are caused by a direct hypofunction of NMDARs. Hence, it appears that MMN is dependent on NMDAR blockade, whereas PPI is not. Further research is needed to understand why these actions are species specific.

\subsubsection{Neurophysiology}

Brain oscillations have been also studied as possible in vivo biomarkers of the illness. Schizophrenic patients frequently show EEG abnormalities [36,37] and a closer look of these changes can bring some evidence about the pathogenesis of the illness. Oscillations in the $\gamma$ band $(30-100 \mathrm{~Hz})$ have been the object of interest, because of their involvement in cognitive functions known to be impaired in schizophrenia [37-43]. Cortical $\gamma$ oscillations result from the control that parvalbumin-containing $\gamma$-aminobutyric acid (GABA)ergic interneurons exert over pyramidal neurons $[44,45]$ and, in this regard, abnormalities in these cortical interneurons have been consistently found in schizophrenia [42,46-48]. A preferential blockade of NMDA receptors on parvalbumin-expressing (PV) interneurons is postulated as a central mechanism of classical actions of NMDA receptor antagonists, which results in increased cortical activity and $\gamma$-band oscillations [49-53]. Further, schizophrenia is characterized by abnormalities in $\gamma$ oscillations measured in different cognitive tasks. Thus, schizophrenic patients exhibit increases in spontaneous gamma band power [42,43], which have been related to positive symptoms [54-56]. However, marked deficits in the $\gamma$ frequency band were observed when $\gamma$ oscillations were examined under different tasks (for instance, auditory-evoked responses) [39,42,57,58]. However, at variance to what happen in rodents (see below), NMDAR antagonists, such as ketamine, usually elicit increases in spontaneous $\gamma$ band power, probably evoked by an excessive stimulation of glutamatergic 
transmission in cortical and subcortical areas [42,43,59-61]. Although no direct measure of brain glutamate level can be determined from the brain of schizophrenics, some indirect estimates have implicated increased activation of prefrontal cortex in first-episode schizophrenia [62-64] and after ketamine administration $[65,66]$, which can be taken as suggestive of increased glutamate release in the human brain.

In addition to high frequency oscillations, low frequency oscillations $(\alpha, \theta$ and $\delta$ bands) are also related to cognitive processing. For instance, the $\alpha$ wave range $(8-12 \mathrm{~Hz})$ is related to working memory processes [67], whereas the $\theta$ range $(5-8 \mathrm{~Hz})$ is involved in attention and signal detection [68], which reflects cortico-hippocampal interactions [69-71]. On the other hand, oscillations in the $\delta$ band are also involved in decision making procedures [68].

\subsubsection{Post-Mortem Studies}

Another important line of investigation aimed at examining the implication of NMDAR in schizophrenia has been the study of post-mortem tissue. Thus, decreased cortical expression of NMDAR subunits have been observed in subjects with schizophrenia, though not in a consistent manner [72], depending on the brain region examined and methodology used. In this regard, decreased transcripts coding for the GluN1 subunit have been found in the prefrontal cortex $[73,74]$ and hippocampal subregions [75,76]. However, as aforementioned, care must be taken, because some of these changes are also observed in different psychiatric conditions and, by no means, are compelling, as long as contradictory results have been found. As a matter of fact, this same meta-analysis found no consistent statistically significant changes in cortical mRNA and protein expression of GluN2A, GluN2B and GluN2D subunits in schizophrenia, with the exception of decreased expression of mRNA coding for GluN2C $[74,77,78]$. Of note, in the postsynaptic density compartment of human post-mortem prefrontal cortex, an important reduction in the density of the postsynaptic protein PSD-95 [74] and in the activity of signaling cascades downstream of the NMDAR has been found in schizophrenia [79].

Since the finding that the therapeutic efficacy of antipsychotic drugs was directly correlated to their affinity for dopamine D2 receptors [80,81], it was first postulated that altered dopamine D2-like receptors was responsible for schizophrenia symptoms. However, this was not confirmed until the study by Abi-Dargham [82], which reported increased occupancy of dopamine D2 receptors in schizophrenia. Moreover, it was evidenced that the administration of ketamine to healthy subjects enhanced the release of dopamine in ventral striatum, which was shown to correlate strongly with the emergence of psychotic symptoms [83]. For these reasons, an association between D2-like receptors and NMDA hypofunction was hypothesized $[84,85]$. In addition to these findings, the differential expression of some splice variants might also evoke abnormal NMDAR trafficking and plasma membrane insertion, which may lead to abnormalities seen in schizophrenia patients $[86,87]$.

Another important issue is the role of astrocytes in schizophrenia. High levels of extracellular glutamate are associated with excitotoxicity, and astrocytes are the principal cells that contribute to glutamate homeostasis through its removal from the synapsis, by means of selective reuptake mechanisms. The excitatory amino acid transporters 1 and 2 (EAAT1/2) are predominantly localized on astrocytes and are mainly responsible for clearing synaptic glutamate and influencing postsynaptic responses. Post-mortem studies have reported that EAAT1 expression is decreased in schizophrenia, as compared to healthy subjects [88]. Additionally, the activation of EAAT2 and its transport to plasma membrane was found to be reduced in schizophrenic brains [89]. A genetic variant of EAAT2 (SNP rs4354668) has been correlated with the severity of schizophrenia [90]. Altogether, these findings are consistent with an impairment of astrocyte function in schizophrenia [91].

\subsection{Preclinical Evidence}

Mental disorders, such as schizophrenia and depression, are illnesses uniquely human, in that they are diagnosed using different interview questionnaires. Therefore, no animal model can recreate the full spectrum of their symptoms. However, some models exist that examine changes in behavioral and 
neurophysiological readouts that are compatible with changes that are also observed in patients. For instance, the acute, systemic administration of NMDAR antagonists induces, in rodents, hyperlocomotion and stereotypical behaviors [92], which are potentially compatible to positive symptoms of schizophrenia $[93,94]$, in that they are associated with increased dopaminergic and serotonergic transmission in the brain $[95,96]$. NMDAR antagonists, such as PCP and dizocilpine (MK-801), also produce severe disruptions in PPI, and deficits in different domains of cognition in rats $[97,98]$. Acute NMDAR antagonism also evokes an increased firing rate of pyramidal neurons and expression of c-fos mRNA of the prefrontal cortex [99-103], which suggests an overall, excessive prefrontal activity, which results in elevated release of glutamate [104-106], dopamine [107-109], 5-HT [110-112] and acetylcholine [113,114] in the medial prefrontal cortex (mPFC) of rats. Altogether these findings indicate that an overstimulation of different transmitter systems in the mPFC is a general response to NMDAR hypofunction, which can account for the behavioral effects induced by NMDAR antagonists. The enhanced release of monoamines most likely result from the stimulation of prefrontal excitatory glutamatergic inputs onto midbrain dopamine and 5-HT cell groups, as suggested by recent investigations $[115,116]$. It is paradoxical that a blockade of excitatory glutamatergic receptors, such as NMDARs, results in the stimulation of glutamate release. The most accepted hypothesis to explain this phenomenon is the disinhibition theory $[49,104,117]$, which postulates that NMDA antagonists would block NMDA receptors located on tonically active GABAergic neurons, which would control glutamatergic output. This would diminish GABAergic inhibition, thus disinhibiting glutamatergic neurotransmission impinging upon $\alpha$-amino-3-hydroxy-5-methyl-4-isoxazolepropionic acid (AMPA) receptors (Figure 3). The finding that some GABAergic interneurons in hippocampus and neocortex are enriched in NMDAR and receive a greater glutamatergic input in comparison with pyramidal neurons, gives further cellular support to this view $[118,119]$.

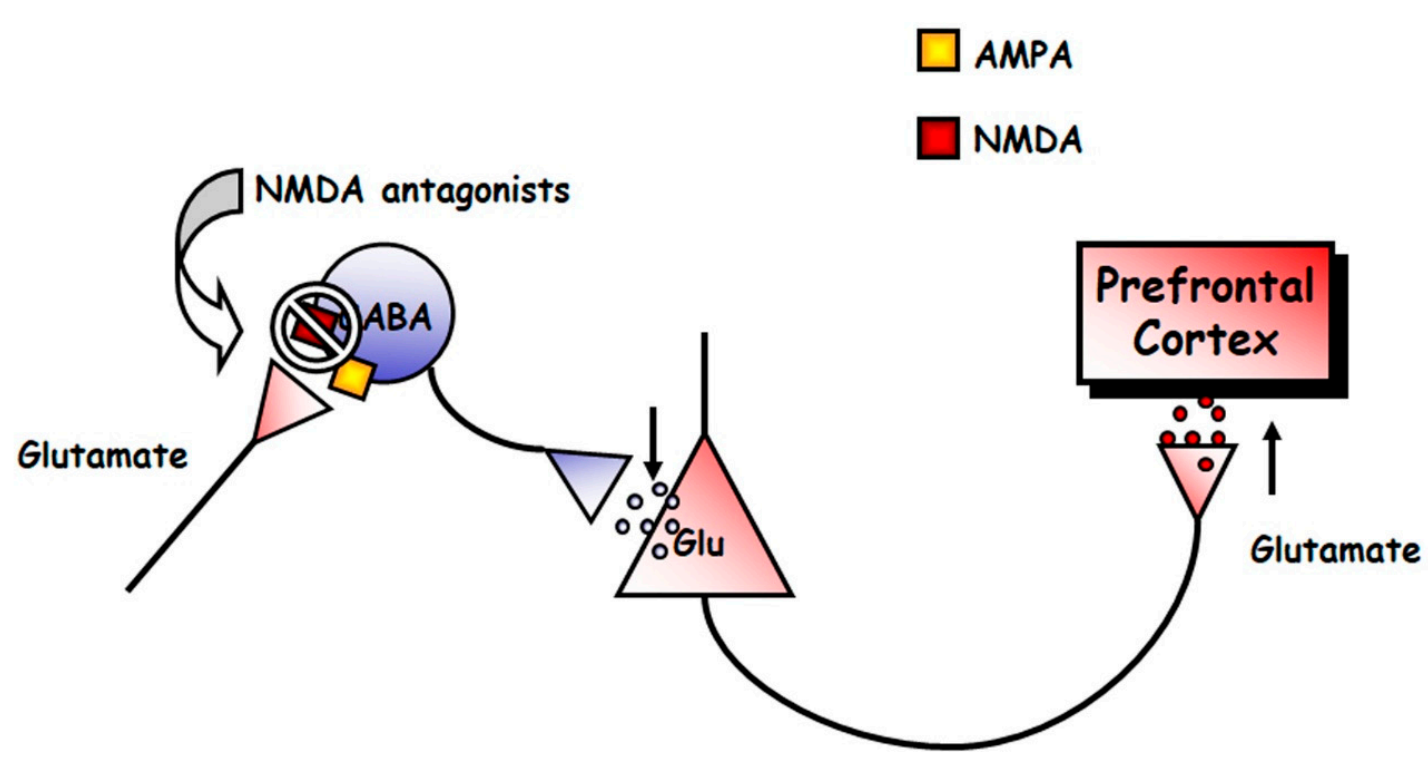

Figure 3. Scheme of the mechanism of action of NMDAR antagonists. These drugs would block NMDAR in a population of tonically active $\gamma$-aminobutyric acid (GABA)ergic neurons. This would decrease the activity of these neurons, and the consequent decrease in GABA release would cause the disinhibition of glutamatergic neurotransmission. The glutamate released would lead to the stimulation of $\alpha$-amino-3-hydroxy-5-methyl-4-isoxazolepropionic acid (AMPA) receptors in pyramidal cells, which would result in the described state of hyperactivity.

Interestingly, it has been reported that an action of NMDAR antagonists on the mPFC of both brain hemispheres is needed to model these changes in the mPFC [102]. In addition, transmitter changes have been found in other brain areas. For instance, noncompetitive NMDAR antagonists also enhance 
the efflux of glutamate in the nucleus accumbens [120], acetylcholine in the retrosplenial cortex and hippocampus [121,122], 5-HT in the nucleus accumbens [111], noradrenaline in nucleus accumbens and hippocampus [123-125] and dopamine in limbic areas, such as the nucleus accumbens, hippocampus and ventral pallidum [108,111,113,126-128], although these effects were less pronounced than in the mPFC.

\subsubsection{Neurophysiology}

Abnormal oscillatory patterns have been also observed in rodent models. Hence, systemic administration, and even the local administration of PCP, MK-801 or ketamine into some brain regions, increase $\gamma$ and high frequency oscillations (HFO) in a number of cortical and subcortical structures (see [129], for a review). It has also been observed that ketamine and MK-801 reduced the frequency and power of $\theta$ oscillations in the hippocampus $[130,131]$. Furthermore, acute PCP also alters thalamo-cortical oscillations, particularly those below the $4 \mathrm{~Hz}$ band [132].

\subsubsection{Animal Models}

The modeling of schizophrenia has been achieved not only by acute, but also by long-term administration of NMDAR antagonists [133]. Thus, although the nature of some changes is similar, following acute or protracted treatment with NMDAR antagonists, it has been postulated that changes after the acute regimen are more comparable with those occurring in early stages of schizophrenia, whereas the duration of such changes after sustained administration appears to be more related to the persistence of clinical symptoms of the illness [134-138]. Acute PCP treatment increased locomotor activity in rodents, an effect potentiated after long-term treatment [139-141]. Subchronic PCP treatment does not seem to affect basal and PCP-induced 5-HT efflux in the mPFC. However, in comparison to acute administration, subchronic PCP attenuated basal prefrontal dopamine release, but potentiated PCP-induced dopamine efflux. The reduced basal extracellular concentration of dopamine could be accounted for by lowering its synthesis, as measured by a diminished expression of tyrosine hydroxylase mRNA in the ventral tegmental area [141].

Preclinical evidence from animal models also reported impairment of astrocyte function in the schizophrenia model of repeated MK-801 exposure [142]. In addition, abnormal EAAT1/2 function is associated with schizophrenia phenotypes. For instance, mice lacking EAAT1 showed hyperlocomotion and increased sensitivity to the locomotor hyperactivity produced by NMDAR antagonists [143]. In addition, the hyperlocomotion of these EAAT1 knockout mice was reversed by the antipsychotic haloperidol.

\section{NMDA Receptors as Target for Treatment in Schizophrenia}

A plethora of antipsychotic drugs have been approved for the treatment of schizophrenia, most of them targeting monoamine receptors. Nevertheless, although hypofunction of NMDA neurotransmission has been shown to play an important role in the pathophysiology of schizophrenia, the results of the clinical trials of the NMDA-enhancing agents have been inconsistent. Since direct agonists of the NMDA receptor can produce severe excitotoxic effects, the therapeutic focus turned to the obligatory glycine co-agonist site of the NMDAR (NMDA-glycine site). Thus, drugs stimulating the NMDA-glycine site were postulated to be effective in treating the symptoms of schizophrenia [144]. These types of drugs include glycine itself [145-147], other agonists of the NMDA-glycine recognition site such as D-serine [148-150] and the partial agonist D-cycloserine [151-155], as well as inhibitors of glycine transporters, such as sarcosine ( $N$-methyl-glycine), which increase the synaptic availability of glycine [156,157]. However, although preclinical studies in rodents showed that partial glycine site agonists and glycine reuptake inhibitors exhibit comparable pro-cognitive effects with the potential for the treatment of schizophrenia [158], a double-blind, randomized clinical trial concluded that neither glycine nor D-cycloserine is a generally effective therapeutic option for treating negative symptoms or 
cognitive impairments [147]. As a matter of fact, most clinical trials conducted to date have failed to show efficacy of these agents for the treatment of schizophrenia [159].

First generation (typical) antipsychotics like haloperidol and chlorpromazine potently block dopamine $\mathrm{D}_{2} / \mathrm{D}_{3} / \mathrm{D}_{4}$. The blockade of dopamine $\mathrm{D}_{2}$ receptors in the mPFC is postulated to alleviate psychotic symptoms (delusions, hallucinations). However, the same action in other areas of the brain can cause severe extrapyramidal side-effects (EPS) and hyperprolactinemia [160]. Second generation (atypical) antipsychotic drugs, like clozapine and olanzapine, retain some degree of dopamine $\mathrm{D}_{2} / \mathrm{D}_{3} / \mathrm{D}_{4}$ antagonism, but they possess a superior antagonism at $5-\mathrm{HT}_{2 \mathrm{~A} / 2 \mathrm{C}}$ receptors. These features seem to be more effective for negative symptoms and cognitive deficits, although some side-effects (weight gain, impairment of glucose and lipid metabolism) may emerge [161]. Microdialysis studies carried out in our lab showed that the NMDAR antagonist, MK-801, elevated the release of glutamate and 5-HT in the mPFC $[162,163]$. Our results showed that typical antipsychotics, such as haloperidol and chlorpromazine, and atypical antipsychotics, such as clozapine and olanzapine, were able to attenuate the excess of prefrontal glutamate, but only atypical drugs were able to further reduce the excess of prefrontal 5-HT [163]. Thus, our results further suggest that the blockade of an exacerbated 5-HT release in the MPFC induced by NMDAR antagonists can be a good indicator of "atypicality" of antipsychotic drugs. Although this has been established for clozapine and olanzapine (drugs that display a similar pharmacological profile), further research is needed to determine whether this is a distinct feature of other antipsychotic drugs. Interestingly, these effects of haloperidol and chlorpromazine could be mimicked by dopamine $D_{2} / D_{3} / D_{4}$ receptor antagonists, and those of clozapine and olanzapine were reproduced by $5-\mathrm{HT}_{2 \mathrm{~A}}$ receptor antagonists and $5-\mathrm{HT}_{1 \mathrm{~A}}$ receptor agonists $[162,163]$. Therefore, it seems that dopamine $D_{2} / D_{3} / D_{4}$ receptor antagonism is relevant to treat positive symptoms of schizophrenia, but it is conceivable that $5-\mathrm{HT}_{2 \mathrm{~A}}$ receptor antagonism and $5-\mathrm{HT}_{1 \mathrm{~A}}$ receptor agonism, may contribute to a better profile of antipsychotic treatment. In fact, preclinical studies have shown that $5-\mathrm{HT}_{2 \mathrm{~A}}$ antagonists and $5-\mathrm{HT}_{1 \mathrm{~A}}$ agonists can alleviate the cognitive deficits induced by NMDA receptor antagonists [164]. Each of these receptor components do not confer antipsychotic properties individually, so it is likely that a combined effect is needed.

\section{NMDA Receptors in Depression}

\subsection{Clinical Evidence}

Four different findings suggest a relationship between dysfunction of NMDAR and depression. First, an anomalous gene expression of NMDAR has been found in depressed people [165-167]; second, stressors induce excessive NMDAR activity that could result in the pathology of depression [168]; third, NMDAR blockers, such as ketamine (see below), have antidepressant properties [169-171]; and fourth, conventional antidepressant drugs usually impact on NMDAR function [172-174]. Altogether, these investigations suggest an overstimulation of NMDAR in major depression [175-178].

\section{Post-Mortem Studies}

However, the results obtained from these investigations exhibit great variability, and are far from consistent, likely due to differences in the brain structure examined or the methodological procedures used. For instance, post-mortem studies have revealed reduced levels of GluN2A and GluN2B subunits in the prefrontal [179] and perirhinal [180] cortices, but increased levels of GluN2A subunits in the lateral amygdala [181] in major depression. Previous post-mortem work did not find changes in the total content of GluN1 protein in the prefrontal cortex in depression [179,182]. Yet, when splice isoforms were considered, NMDAR activity and the GluN1 subunit carrying the $\mathrm{C} 1$ cytosolic segment were found to be increased in depressives [182]. Another report also described that the GluN2C subunit is elevated in the locus coeruleus of patients with major depression [183]. Further, early life adverse effects reduce NMDAR binding in dorsolateral prefrontal and anterior cingulate cortices, which could result from excessive NMDAR stimulation [184]. This would be consistent with the hypothesis of 
glutamate excitotoxicity produced by stress-induced excessive NMDAR activity, which could induce depressive states [168,185].

Further work has reported higher expression levels of the NMDAR subunit genes, GRIN2B and GRIN2C, in the locus coeruleus of depressed patients [186]. Another study reported a higher expression of GRIN1, GRIN2A, GRIN2B, GRIN2C and GRIN2D subunit mRNAs, but only in female MDD patients. Nevertheless, when male and female patients were grouped, the expression of GRIN2B mRNA was higher in those who committed suicide, in comparison with those that suffered depression but did not die by suicide [187]. For this reason, GRIN2B mRNA level is rather considered as biomarker of suicide and, in fact, polymorphisms of GRIN2B have been postulated to predict treatment-resistant depression $[165,188]$. Further epigenetic work showed that methylation in GRIN1 was a significant predictor of depression in a sample of maltreated children [189].

Although there is a great number of genome wide association studies (GWAS) that have examined genetic changes in depression, much less attention so far has been devoted to the study of gene methylation. In this regard, only one study has found a hypermethylation of the GRIN2A gene body in the hippocampus and prefrontal cortex of post-mortem human tissue in depression [167], which has been attributed to overexpression of the GluN2A subunit [190].

Other post-mortem studies have revealed the influence of astrocytes in MDD (see [191,192] for review). Thus, there is mounting evidence that the number and morphology of astrocytes are altered in depression, particularly in the frontal cortex [193-195] and the dentate gyrus of the hippocampus [196]. A significant reduction of the packing density of glial fibrillary acidic protein (GFAP)-containing astrocytes was also found, but only in younger (30-45 years old) patients [197].

\subsection{Preclinical Evidence}

There is substantial evidence from rodent models relevant to depression that stress induces glutamatergic hyperactivity, as well as the overexpression of NMDARs [198-200]. Given that NMDAR antagonists exert a preferential blockade of NMDAR on PV interneurons, enhanced PV interneuron activity has been observed after stress and might underlie depression-like behavior [201-203]. However, this is not a universal picture inasmuch as decreased PV cell activity has been observed after different stressful conditions (see [204], for review).

Maternal separation induces increased expression of GluN2A (but not GluN2B) subunit of NMDARs in the hippocampus of adult rats [205]. Chronic restraint stress significantly elevated GRIN2a (GluN2A) and GRIN2b (GluN2B) subunit genes in BALB/c mice, but not in C57BL/6 mice [206]. Chronic restraint stress also increased the levels of GRIN1 mRNA, along with a reduction in protein levels in dorsal hippocampus [207]. Chronic corticosterone administration, which emulates the endocrine response to stress, increased GRIN2A and GRIN2B mRNAs, which mediated the deleterious effects on the hippocampus [208]. Further, the olfactory bulbectomy model of depression reduces NMDA receptor binding in the prefrontal cortex and amygdala $[209,210]$. On the other hand, in the frontal cortex, BDNF deficiency, which occurs under chronic stress and is one of the leading causes of depression, also increased the density of GRIN1, GRIN2A and GRIN2B genes in the early stages of development [211]. Therefore, with all these findings taken together, a logical reasoning would hypothesize that the deletion or inhibition of NMDAR subunits would have antidepressant-like effects. Indeed, inactivation of the GluN2A subunit has been shown to evoke antidepressant-like activity in mice [212]. Yet, the deletion of the GluN2D subunit in the bed nucleus of the stria terminalis (BNST) increases depressive-like behaviors [213]. However, mice with constitutive, global deletion of the GluN1 or GluN2B subunits die neonatally. Homozygous GRIN1 knockout mice only survive 8-15 h after birth [214], and homozygous GRIN2b knockout mice die at early postnatal stages, because of an impaired suckling response [215].

However, the same as occurs with human studies, work with experimental animals has also yielded contradictory results. Thus, increased GRIN1 mRNA expression in the mPFC appears to have antidepressant-like effects in the forced swim test. [216]. GRIN1 was also found to be downregulated 
in chronic unpredictable mild stress (CUMS) [217]. The type and duration of the stressor, as well as the brain region examined, may underlie these differences.

Alterations in the number and/or function of astrocytes have also been found in animal models of depression (see [218] for review). Indeed, a reduced number and volume of astrocytes was found in the prefrontal cortex [219] and the hippocampus [220], in the chronic unpredictable stress procedure and chronic social defeat stress paradigm. Interestingly, neurotoxic lesioning of astrocytes in the prefrontal cortex is sufficient to induce depressive-like behaviors in rodents [221], an effect also found after knocking-down the expression of astrocytic glutamate transporter GLAST/GLT-1 in the prefrontal cortex of the mouse, using small interfering RNA (siRNA) strategies [222].

\section{NMDA Receptors as Target for Treatment in Depression}

Conventional antidepressant drugs inhibit monoamine transporters, based upon the assumption that a deficit in the synaptic concentration of monoamines are the underlying cause of depression. However, monoamine-based antidepressants have important limitations, such as lower efficacy, therapeutic delay and, above all, the existence of a population of patients (estimated as one third of depressed people) that do not respond to the treatment [223-225]. Thus, alternative therapeutic goals have focused on the neurotransmitter glutamate and its receptors, particularly in the ionotropic NMDAR. The first indication that NMDAR blockers had antidepressant-like effects dates back to 1990, when Trullas and Skolnick [226] reported that both competitive and non-competitive NMDAR antagonists reduced immobility in the forced swim (FST) and tail suspension (TST) tests. Three decades later, and after intensive research, esketamine (Spravato ${ }^{\circledR}$ ) was approved by the US Food and Drug Administration (FDA) and the European Medicines Agency (EMA) for adults with major depression who are resistant to treatment, although with rigorous restrictions. In the past decade, clinical investigations have shown that a single intravenous bolus administration of the non-competitive NMDAR antagonist, ketamine, evoked a rapid (in only $2 \mathrm{~h}$ ) and sustained (lasting up to 7 days) antidepressant action $[169,170,227,228]$. Interestingly, the dosage of ketamine used for antidepressant action (a total dose of $0.5 \mathrm{mg} / \mathrm{kg}$ infused over $40 \mathrm{~min}$ ) is comparable to the one used to evoke psychotic symptoms in healthy volunteers [21]. Thus, it seems that ketamine can exert a similar enhancing modulatory function in mental status, i.e., increasing the emotional condition and mood in depressives, and increasing extremely disordered thinking and behavior in healthy controls, and both conditions can be triggered by stress (Figure 4). Although the mechanism of action of ketamine is not completely understood, the involvement of several cellular and molecular processes has been unveiled. Hence, its antidepressant-like action requires the activation of another class of ionotropic glutamate receptors, the $\alpha$-amino-3-hydroxy-5-methyl-4-isoxazolepropionic acid (AMPA) receptors [229-231], and the stimulation of mammalian (or mechanistic) target of rapamycin (mTOR), an intracellular pathway associated with synaptic plasticity $[232,233]$. Further, it has been observed that ketamine also facilitates the expression of the GluA1 subunit of the AMPA receptor [232,234-236]. mTOR seems to be specific to rapid-acting antidepressants, because other conventional antidepressant drugs, such as imipramine and fluoxetine, do not require mTOR signaling. mTOR is a serine/threonine protein kinase that regulates the initiation of protein translation, thus inducing the protein synthesis required for synaptogenesis $[237,238]$, a process needed for antidepressant action. As a matter of fact, recent studies have found reduced mTOR function in the prefrontal cortex of depressives [239], and in the frontal cortex, amygdala and hippocampus of rats exposed to chronic stress [240-242]. 


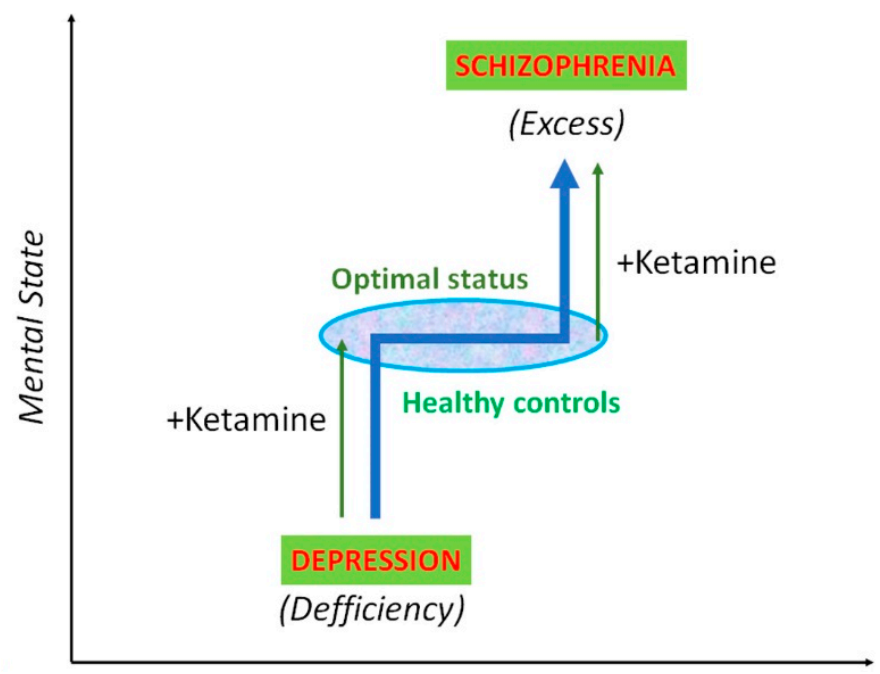

Figure 4. Schematic representation of mental state that appears as a continuum that can be modulated by ketamine. Ketamine can alleviate depressive symptoms in patients, but also induce psychotic symptoms when administered to healthy subjects. The terms deficiency and excess are abstract concepts herein, but can refer, for instance, to cortical monoamine levels.

The antidepressant-like actions of systemic ketamine were reproduced by the microinfusion of the drug into the infralimbic cortex [243,244], thus underscoring the importance of this brain region in the antidepressant effects of ketamine. Furthermore, the optogenetic stimulation of the pyramidal cells in the mPFC that project to the dorsal raphe nucleus (DRN, the nucleus where most serotonergic neurons that innervate forebrain structures originate) produces antidepressant effects [243,245-247], which reproduced the response elicited by the intracortical administration of ketamine [243]. Therefore, it is postulated that the rapid antidepressant-like effects of ketamine are accounted for by the glutamate-induced AMPA receptors localized to layer 5 pyramidal neurons that project to the DRN [243], thus releasing 5-HT in the MPFC, which would contribute to the antidepressant response. Given that ketamine also elevated the release of dopamine and noradrenaline in the $\mathrm{mPFC}$, it is conceivable that ketamine would also activate the projections from the mPFC to the dopaminergic ventral tegmental area and the noradrenergic locus coeruleus. Altogether, the rapid enhancement of the release of 5-HT, dopamine and noradrenaline in the MPFC would contribute to the rapid antidepressant response of ketamine [116] (Figure 5).

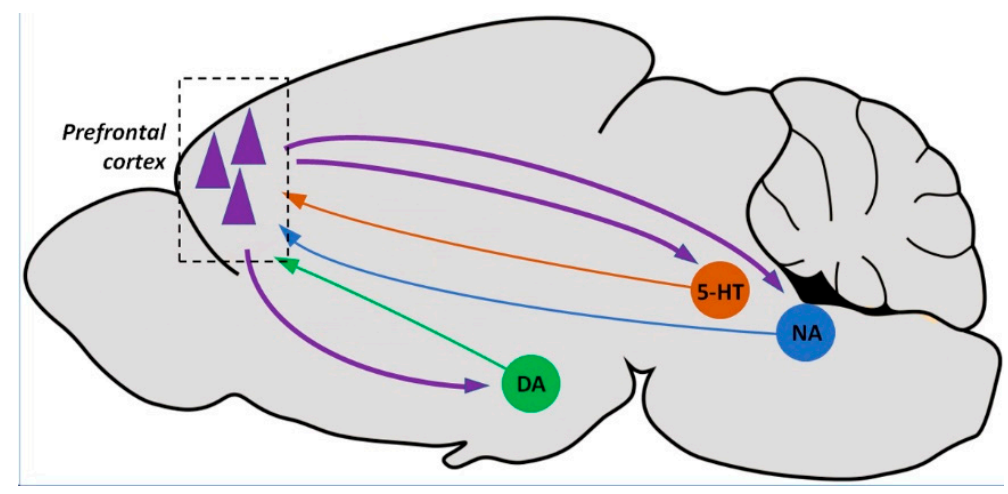

Figure 5. Prefrontal pyramidal neurons (dashed line square) project to the dopaminergic neurons of the ventral tegmental area, serotonergic neurons of the dorsal raphe nucleus and noradrenergic neurons of the locus coeruleus. Neurons from these monoaminergic nuclei send projections back that modulate the neuronal activity of prefrontal cortex. 
Indeed, the mPFC has been traditionally implicated in alertness and attentional processes, working memory and behavioral flexibility, behaviors known to be associated with noradrenaline, dopamine and 5-HT, respectively, and impaired in mood disorders. However, despite the widespread recognition of the involvement of monoamines in depression [248], there is a lack of compelling evidence linking depression to low serotonergic and/or noradrenergic and/or dopaminergic transmissions. A possible explanation could be that a greater than $90 \%$ depletion of one of more monoamines would be required for the emergence of depressive states. For instance, serotonin depletion does not usually alter immobility in the FST [249], but we recently demonstrated that, when this depletion was $90 \%$, immobility was significantly increased [115]. Severity of depression is positively associated with the frequency and severity of somatic symptoms [250-253], which depends on the monoamine levels [254,255]. Old clinical work, which would be hardly reproducible in present days for obvious bioethical reasons, showed that, in hospitalized, depressed patients who had responded to treatment with tranylcypromine (a monoamine oxidase inhibitor) or imipramine (a tricyclic antidepressant), depressive symptomatology returned after small doses of parachlorophenylalanine (an irreversible inhibitor of the synthesis of 5-HT) [256,257]. Perhaps this has been the only work so far that evidenced the appearance of depression symptoms after the depletion of body 5-HT.

As aforementioned, the approval of the (S)-isomer of ketamine has come with serious restrictions, because of the drug can cause dissociation and delirium at the low doses used for depression. These adverse effects appear shortly after infusion onset but vanish just before the antidepressant response begins [169]. In attempts to overcome such problems, other ketamine-based alternatives have been pursued. The approved $(S)$-ketamine has $\sim 4$-fold greater affinity for NMDARs than the $(R)$-ketamine. On the other hand, $(S)$-ketamine displays a greater anesthetic potency and greater undesirable psychotomimetic side effects than $(R)$-ketamine [258,259]. Furthermore, a recent study by Hashimoto and co-workers established that $(R)$-ketamine had greater potency and longer-lasting antidepressant effects than (S)-ketamine in a rodent model of depression [260]. For this reason, this group of investigators proposed the R-stereoisomer of ketamine as an alternative for treatment-resistant major depression [261], because $(R)$-ketamine does not seem to cause psychotomimetic behaviors, neurotoxicity and abuse potential in animal models [260,262,263]. To the best of my knowledge, at present, there is only one open-label pilot study published that examined the antidepressant effects of $(R)$-ketamine [264] and one phase I clinical trial that evaluates the safety and pharmacokinetics of $(R)$-ketamine in healthy subjects (ClinicalTrials.gov Identifier: NCT04108234).

Another strategy has been to examine the antidepressant effects of subunit-selective NMDARs. Ketamine is a non-subunit-selective NMDAR antagonist, and it was hypothesized that perhaps other NMDAR antagonists selective for GluN2A or GluN2B would possess antidepressant activity in the absence of psychotomimetic effects. In this regard, preclinical studies have shown that the GluN2B subunit NMDAR receptor antagonist, Ro 25-6981, possesses antidepressant-like effects [229,232]. Furthermore, in the clinic, several investigational drugs have exhibited some efficacy in the treatment of depressive states, such as the GluN2B receptor antagonists CP-101,606 [265]) and MK 0657 [266], the NMDAR glycine site partial agonist rapastinel (GLYX-13) [267], and the low-trapping nonselective NMDA channel blocker lanicemine (AZD6765) [268,269]. However, the rapid and robust effects of ketamine are clear, whereas the effects of MK 0657 and lanicemine are comparatively modest and short-lived. Although these compounds showed an initial promise for treating depression, further clinical studies failed to exhibit efficacy and the research and development of these compounds were eventually discontinued. In contrast, less attention has been paid to GluN2A antagonists. To this end, we assessed the biochemical and behavioral changes elicited by NVP-AAM077 [270], a competitive antagonist showing 10-fold greater selectivity for the rat GluN2A than for the GluN2B subunit [271], and compared with the effects of Ro 25-6981, which is 5000-fold selective for GluN2B over GluN2A subunit [272]. Our results showed that NVP-AAM077 and Ro 25-6981 possess antidepressant-like activity, and that neither of these compounds alone exhibit psychotomimetic-like activity [273]. However, the combination of NVP-AAM077 and Ro 25-6981 was sufficient to produce stereotypical 
behavior, which is associated to psychotic symptoms [273]. This would suggest that the blockade of either one of these subunits is sufficient to elicit an antidepressant-like action, but only when both subunits are blocked, psychotic-like effects would appear.

The GluN2D subunit has also been implicated in in some of the effects of the treatment with ketamine. Thus, it has been reported that the GluN2D subunit is crucial for the sustained antidepressant effects of $(R)$-ketamine. [274]. Further work from the same group of investigators has suggested that the GluN2D subunit plays also a role in cases of cognitive impairment induced by $(R)$-ketamine, whereas this subunit does not appear to be involved in cognitive impairment that is induced by $(R, S)$-ketamine or $(S)$-ketamine. [249,275].

Contrary to ketamine, the therapeutic mechanisms of conventional antidepressant drugs do not influence glutamatergic transmission in the brain neither under acute nor chronic regimen [276,277]. This lack of impact on glutamate, together with the fact that these drugs do not use mTOR as intracellular signal (see above), indicate that the antidepressant action of rapid-acting and conventional drugs follows different pathways.

\section{Conclusions}

In summary, ketamine has been used to model schizophrenia and to treat refractory depression. In both cases, the mechanism of action appears to be the same one, i.e., ketamine evokes cortical disinhibition by preferentially blocking NMDARs localized to PV interneurons $[278,279]$. Further work has suggested that blockade of GluN2B-containing NMDARs is responsible of the antidepressant-like effects of ketamine $[279,280]$. In fact, the excessive inhibition of hippocampal pyramidal neurons mediated by PV interneurons might contribute to depression-like behavior in an animal model [203] and GABA interneurons are the cellular trigger for ketamine's rapid antidepressant actions. It is possible that psychosis is an immediate consequence of NMDA receptor blockade and reflects, in part, the ability of ketamine to induce glutamate release [104,281]. However, the antidepressant response emerges later, when glutamate released by ketamine would stimulate AMPA receptors [229,231,282]. Thus, both actions are mechanistically associated but temporally dissociated. It has been recently postulated that the mechanisms of rapid-acting antidepressant drugs converge on GluA1 receptors [236]. Thus, ketamine blocks the NMDAR channel, which leads to increases in extracellular glutamate and synapse number in the prefrontal cortex. This glutamate stimulates AMPA receptors which, through an activation of mTOR signaling pathway, induces a rapid synthesis of new proteins-in particular, BDNF and the GluA1 subunit- that are responsible for the rapid antidepressant effects.

Funding: This work was supported by the Instituto de Salud Carlos III, Subdirección General de Evaluación y Fomento de la Investigación (FIS Grants PI16/00217 and PI19/00170) that was co-funded by the European Regional Development Fund ('A way to build Europe'). Funding from the Centro de Investigación Biomédica en Red de Salud Mental (CIBERSAM), Instituto de Salud Carlos III is also acknowledged. The funding agencies had no role in the design and conduct of the study, collection, management, analyses, and interpretation of the data; and preparation, review, or approval of the manuscript and the decision to submit it for publication. We also acknowledge support of the publication fee by the CSIC Open Access Publication Support Initiative through its Unit of Information Resources for Research (URICI).

Conflicts of Interest: The author declares no conflict of interest.

\section{References}

1. Pittenger, C.; Sanacora, G.; Krystal, J.H. The NMDA receptor as a therapeutic target in major depressive disorder. CNS Neurol. Disord. Drug Targets 2007, 6, 101-115. [CrossRef]

2. Hall, J.; Trent, S.; Thomas, K.L.; O’Donovan, M.C.; Owen, M.J. Genetic risk for schizophrenia: Convergence on synaptic pathways involved in plasticity. Biol. Psychiatry 2015, 77, 52-58. [CrossRef]

3. Pittenger, C.; Duman, R.S. Stress, depression, and neuroplasticity: A convergence of mechanisms. Neuropsychopharmacology 2008, 33, 88-109. [CrossRef] [PubMed]

4. Collingridge, G.L.; Kehl, S.J.; McLennan, H. Excitatory amino acids in synaptic transmission in the Schaffer collateral-commissural pathway of the rat hippocampus. J. Physiol. 1983, 334, 33-46. [CrossRef] 
5. Malenka, R.C. Synaptic plasticity in the hippocampus: LTP and LTD. Cell 1994, 78, 535-538. [CrossRef]

6. Traynelis, S.F.; Wollmuth, L.P.; McBain, C.J.; Menniti, F.S.; Vance, K.M.; Ogden, K.K.; Hansen, K.B.; Yuan, H.; Myers, S.J.; Dingledine, R. Glutamate receptor ion channels: Structure, regulation, and function. Pharmacol. Rev. 2010, 62, 405-496. [CrossRef]

7. Ulbrich, M.H.; Isacoff, E.Y. Rules of engagement for NMDA receptor subunits. Proc. Natl. Acad. Sci. USA 2008, 105, 14163-14168. [CrossRef]

8. Monyer, H.; Burnashev, N.; Laurie, D.J.; Sakmann, B.; Seeburg, P.H. Developmental and regional expression in the rat brain and functional properties of four NMDA receptors. Neuron 1994, 12, 529-540. [CrossRef]

9. Hansen, K.B.; Yi, F.; Perszyk, R.E.; Furukawa, H.; Wollmuth, L.P.; Gibb, A.J.; Traynelis, S.F. Structure, function, and allosteric modulation of NMDA receptors. J. Gen. Physiol. 2018, 150, 1081-1105. [CrossRef]

10. Dingledine, R.; Borges, K.; Bowie, D.; Traynelis, S.F. The glutamate receptor ion channels. Pharmacol. Rev. 1999, 51, 7-61.

11. Chergui, K. Dopamine induces a GluN2A-dependent form of long-term depression of NMDA synaptic responses in the nucleus accumbens. Neuropharmacology 2011, 60, 975-981. [CrossRef]

12. Mullasseril, P.; Hansen, K.B.; Vance, K.M.; Ogden, K.K.; Yuan, H.; Kurtkaya, N.L.; Santangelo, R.; Orr, A.G.; Le, P.; Vellano, K.M.; et al. A subunit-selective potentiator of NR2C- and NR2D-containing NMDA receptors. Nat. Commun. 2010, 1, 90. [CrossRef] [PubMed]

13. Hardingham, G.E.; Fukunaga, Y.; Bading, H. Extrasynaptic NMDARs oppose synaptic NMDARs by triggering CREB shut-off and cell death pathways. Nat. Neurosci. 2002, 5, 405-414. [CrossRef] [PubMed]

14. Le Meur, K.; Galante, M.; Angulo, M.C.; Audinat, E. Tonic activation of NMDA receptors by ambient glutamate of non-synaptic origin in the rat hippocampus. J. Physiol. 2007, 580, 373-383. [CrossRef]

15. Lozovaya, N.A.; Grebenyuk, S.E.; Tsintsadze, T.; Feng, B.; Monaghan, D.T.; Krishtal, O.A. Extrasynaptic NR2B and NR2D subunits of NMDA receptors shape 'superslow' afterburst EPSC in rat hippocampus. J. Physiol. 2004, 558, 451-463. [CrossRef]

16. Thomas, C.G.; Miller, A.J.; Westbrook, G.L. Synaptic and extrasynaptic NMDA receptor NR2 subunits in cultured hippocampal neurons. J. Neurophysiol. 2006, 95, 1727-1734. [CrossRef]

17. Janssen, W.G.; Vissavajjhala, P.; Andrews, G.; Moran, T.; Hof, P.R.; Morrison, J.H. Cellular and synaptic distribution of NR2A and NR2B in macaque monkey and rat hippocampus as visualized with subunit-specific monoclonal antibodies. Exp. Neurol. 2005, 191, S28-S44. [CrossRef]

18. Villmann, C.; Becker, C.M. On the hypes and falls in neuroprotection: Targeting the NMDA receptor. Neuroscientist 2007, 13, 594-615. [CrossRef]

19. Kalia, L.V.; Kalia, S.K.; Salter, M.W. NMDA receptors in clinical neurology: Excitatory times ahead. Lancet Neurol. 2008, 7, 742-755. [CrossRef]

20. Javitt, D.C.; Zukin, S.R. Recent advances in the phencyclidine model of schizophrenia. Am. J. Psychiatry 1991, 148, 1301-1308.

21. Krystal, J.H.; Karper, L.P.; Seibyl, J.P.; Freeman, G.K.; Delaney, R.; Bremner, J.D.; Heninger, G.R.; Bowers, M.B.J.; Charney, D.S. Subanesthetic effects of the noncompetitive NMDA antagonist, ketamine, in humans. Psychotomimetic, perceptual, cognitive, and neuroendocrine responses. Arch. Gen. Psychiatry 1994, 51, 199-214. [CrossRef] [PubMed]

22. Malhotra, A.K.; Pinals, D.A.; Weingartner, H.; Sirocco, K.; Missar, C.D.; Pickar, D.; Breier, A. NMDA receptor function and human cognition: The effects of ketamine in healthy volunteers. Neuropsychopharmacology 1996, 14, 301-307. [CrossRef]

23. Newcomer, J.W.; Farber, N.B.; Jevtovic-Todorovic, V.; Selke, G.; Melson, A.K.; Hershey, T.; Craft, S.; Olney, J.W. Ketamine-induced NMDA receptor hypofunction as a model of memory impairment and psychosis. Neuropsychopharmacology 1999, 20, 106-118. [CrossRef]

24. Malhotra, A.K.; Adler, C.M.; Kennison, S.D.; Elman, I.; Pickar, D.; Breier, A. Clozapine blunts N-methyl-D-aspartate antagonist-induced psychosis: A study with ketamine. Biol. Psychiatry 1997, 42, 664-668. [CrossRef]

25. Lahti, A.C.; Weiler, M.A.; Michaelidis, T.; Parwani, A.; Tamminga, C.A. Effects of ketamine in normal and schizophrenic volunteers. Neuropsychopharmacology 2001, 25, 455-467. [CrossRef]

26. Stone, J.M.; Erlandsson, K.; Arstad, E.; Squassante, L.; Teneggi, V.; Bressan, R.A.; Krystal, J.H.; Ell, P.J.; Pilowsky, L.S. Relationship between ketamine-induced psychotic symptoms and NMDA receptor occupancy: A [ ${ }^{123}$ I] CNS-1261 SPET study. Psychopharmacology (Berl) 2008, 197, 401-408. [CrossRef] [PubMed] 
27. Pilowsky, L.S.; Bressan, R.A.; Stone, J.M.; Erlandsson, K.; Mulligan, R.S.; Krystal, J.H.; Ell, P.J. First in vivo evidence of an NMDA receptor deficit in medication-free schizophrenic patients. Mol. Psychiatry 2006, 11, 118-119. [CrossRef]

28. Kumari, V.; Soni, W.; Mathew, V.M.; Sharma, T. Prepulse inhibition of the startle response in men with schizophrenia: Effects of age of onset of illness, symptoms, and medication. Arch. Gen. Psychiatry 2000, 57, 609-614. [CrossRef]

29. Parwani, A.; Duncan, E.J.; Bartlett, E.; Madonick, S.H.; Efferen, T.R.; Rajan, R.; Sanfilipo, M.; Chappell, P.B.; Chakravorty, S.; Gonzenbach, S.; et al. Impaired prepulse inhibition of acoustic startle in schizophrenia. Biol. Psychiatry 2000, 47, 662-669. [CrossRef]

30. Braff, D.L.; Geyer, M.A.; Swerdlow, N.R. Human studies of prepulse inhibition of startle: Normal subjects, patient groups, and pharmacological studies. Psychopharmacology (Berl) 2001, 156, 234-258. [CrossRef] [PubMed]

31. Duncan, E.J.; Madonick, S.H.; Parwani, A.; Angrist, B.; Rajan, R.; Chakravorty, S.; Efferen, T.R.; Szilagyi, S.; Stephanides, M.; Chappell, P.B.; et al. Clinical and sensorimotor gating effects of ketamine in normals. Neuropsychopharmacology 2001, 25, 72-83. [CrossRef]

32. Shelley, A.M.; Silipo, G.; Javitt, D.C. Diminished responsiveness of ERPs in schizophrenic subjects to changes in auditory stimulation parameters: Implications for theories of cortical dysfunction. Schizophr. Res. 1999, 37, 65-79. [CrossRef]

33. Jessen, F.; Fries, T.; Kucharski, C.; Nishimura, T.; Hoenig, K.; Maier, W.; Falkai, P.; Heun, R. Amplitude reduction of the mismatch negativity in first-degree relatives of patients with schizophrenia. Neurosci. Lett. 2001, 309, 185-188. [CrossRef]

34. Michie, P.T.; Innes-Brown, H.; Todd, J.; Jablensky, A.V. Duration mismatch negativity in biological relatives of patients with schizophrenia spectrum disorders. Biol. Psychiatry 2002, 52, 749-758. [CrossRef]

35. Umbricht, D.; Koller, R.; Vollenweider, F.X.; Schmid, L. Mismatch negativity predicts psychotic experiences induced by NMDA receptor antagonist in healthy volunteers. Biol. Psychiatry 2002, 51, 400-406. [CrossRef]

36. Matsuura, M.; Yoshino, M.; Ohta, K.; Onda, H.; Nakajima, K.; Kojima, T. Clinical significance of diffuse delta EEG activity in chronic schizophrenia. Clin. Electroencephalogr. 1994, 25, 115-121. [CrossRef]

37. Winterer, G.; Coppola, R.; Goldberg, T.E.; Egan, M.F.; Jones, D.W.; Sanchez, C.E.; Weinberger, D.R. Prefrontal broadband noise, working memory, and genetic risk for schizophrenia. Am. J. Psychiatry 2004, 161, 490-500. [CrossRef]

38. Waberski, T.D.; Norra, C.; Kawohl, W.; Thyerlei, D.; Hock, D.; Klostermann, F.; Curio, G.; Buchner, H.; Hoff, P.; Gobbelé, R. Electrophysiological evidence for altered early cerebral somatosensory signal processing in schizophrenia. Psychophysiology 2004, 41, 361-366. [CrossRef]

39. Uhlhaas, P.J.; Singer, W. Abnormal neural oscillations and synchrony in schizophrenia. Nat. Rev. Neurosci. 2010, 11, 100-113. [CrossRef]

40. Sun, Y.; Farzan, F.; Barr, M.S.; Kirihara, K.; Fitzgerald, P.B.; Light, G.A.; Daskalakis, Z.J. Gamma oscillations in schizophrenia: Mechanisms and clinical significance. Brain Res. 2011, 1413, 98-114. [CrossRef]

41. Buzsáki, G.; Wang, X.-J. Mechanisms of gamma oscillations. Annu. Rev. Neurosci. 2012, 35, 203-225. [CrossRef]

42. Tada, M.; Nagai, T.; Kirihara, K.; Koike, S.; Suga Maraki, T.; Kobayashi, T.; Kasai, K. Differential alterations of auditory gamma oscillatory responses between pre-onset high-risk individuals and first-episode schizophrenia. Cereb. Cortex 2016, 26, 1027-1035. [CrossRef]

43. Hirano, Y.; Oribe, N.; Kanba, S.; Onitsuka, T.; Nestor, P.G.; Spencer, K.M. Spontaneous gamma activity in schizophrenia. JAMA Psychiatry 2015, 72, 813-821. [CrossRef]

44. Cardin, J.A.; Carlen, M.; Meletis, K.; Knoblich, U.; Zhang, F.; Deisseroth, K.; Tsai, L.H.; Moore, C.I. Driving fast-spiking cells induces gamma rhythm and controls sensory responses. Nature 2009, 459, 663-667. [CrossRef]

45. Sohal, V.S.; Zhang, F.; Yizhar, O.; Deisseroth, K. Parvalbumin neurons and gamma rhythms enhance cortical circuit performance. Nature 2009, 459, 698-702. [CrossRef]

46. Gonzalez-Burgos, G.; Lewis, D.A. GABA neurons and the mechanisms of network oscillations: Implications for understanding cortical dysfunction in schizophrenia. Schizophr. Bull. 2008, 34, 944-961. [CrossRef]

47. Hashimoto, T.; Arion, D.; Unger, T.; Maldonado-Aviles, J.G.; Morris, H.M.; Volk, D.W.; Mimics, K.; Lewis, D.A. Alterations in GABA-related transcriptome in the dorsolateral prefrontal cortex of subjects with schizophrenia. Mol. Psychiatry 2008, 13, 147-161. [CrossRef] 
48. Moyer, C.E.; Delevich, K.M.; Fish, K.N.; Asafu-Adjei, J.K.; Sampson, A.R.; Dorph-Petersen, K.A.; Lewis, D.A.; Sweet, R.A. Reduced glutamate decarboxylase 65 protein within primary auditory cortex inhibitory boutons in schizophrenia. Biol. Psychiatry 2012, 72, 734-743. [CrossRef]

49. Homayoun, H.; Moghaddam, B. NMDA receptor hypofunction produces opposite effects on prefrontal cortex interneurons and pyramidal neurons. J. Neurosci. 2007, 27, 11496-11500. [CrossRef]

50. Pinault, D. N-methyl D-aspartate receptor antagonists ketamine and MK-801 induce wake-related aberrant gamma oscillations in the rat neocortex. Biol. Psychiatry 2008, 63, 730-735. [CrossRef]

51. Hakami, T.; Jones, N.C.; Tolmacheva, E.A.; Gaudias, J.; Chaumont, J.; Salzberg, M.; O’Brien, T.J.; Pinault, D. NMDA receptor hypofunction leads to generalized and persistent aberrant gamma oscillations independent of hyperlocomotion and the state of consciousness. PLoS ONE 2009, 4, e6755. [CrossRef]

52. Kocsis, B. Differential role of NR2A and NR2B subunits in N-methyl-D-aspartate receptor antagonist-induced aberrant cortical gamma oscillations. Biol. Psychiatry 2012, 71, 987-995. [CrossRef]

53. Sullivan, E.M.; Timi, P.; Hong, L.E.; O’Donnell, P. Reverse translation of clinical electrophysiological biomarkers in behaving rodents under acute and chronic NMDA receptor antagonism. Neuropsychopharmacology 2015, 40, 719-727. [CrossRef]

54. Baldeweg, T.; Spence, S.; Hirsch, S.R.; Gruzelier, J. Gamma-band electroencephalographic oscillations in a patient with somatic hallucinations. Lancet 1998, 352, 620-621. [CrossRef]

55. Lee, K.H.; Williams, L.M.; Haig, A.; Gordon, E. “Gamma (40 Hz) phase synchronicity” and symptom dimensions in schizophrenia. Cogn. Neuropsychiatry 2003, 8, 57-71. [CrossRef]

56. Spencer, K.M.; Nestor, P.G.; Perlmutter, R.; Niznikiewicz, M.A.; Klump, M.C.; Frumin, M.; Martha, E.; Shenton McCarley, R.W. Neural synchrony indexes disordered perception and cognition in schizophrenia. Proc. Natl. Acad. Sci. USA 2004, 101, 17288-17293. [CrossRef]

57. Brenner, C.A.; Krishnan, G.P.; Vohs, J.L.; Ahn, W.Y.; Hetrick, W.P.; Morzorati, S.L.; O’Donnell, B.F. Steady state responses: Electrophysiological assessment of sensory function in schizophrenia. Schizophr. Bull. 2009, 35, 1065-1077. [CrossRef]

58. Woo, T.U.; Spencer, K.; McCarley, R.W. Gamma oscillation deficits and the onset and early progression of schizophrenia. Harv. Rev. Psychiatry 2010, 18, 173-189. [CrossRef]

59. Plourde, G.; Baribeau, J.; Bonhomme, V. Ketamine increases the amplitude of the 40-Hz auditory steady-state response in humans. Br. J. Anaesth. 1997, 78, 524-529. [CrossRef]

60. Hong, L.E.; Summerfelt, A.; Buchanan, R.W.; O’Donnell, P.; Thaker, G.K.; Weiler, M.A.; Lahti, A.C. Gamma and delta neural oscillations and association with clinical symptoms under subanesthetic ketamine. Neuropsychopharmacology 2010, 35, 632-640. [CrossRef]

61. Kocsis, B.; Brown, R.E.; McCarley, R.W.; Hajos, M. Impact of ketamine on neuronal network dynamics: Translational modeling of schizophrenia-relevant deficits. CNS Neurosci. Ther. 2013, 19, 437-447. [CrossRef] [PubMed]

62. Callicott, J.H.; Bertolino, A.; Mattay, V.S.; Langheim, F.J.; Duyn, J.; Coppola, R.; Goldberg, T.E.; Weinberger, D.R. Physiological dysfunction of the dorsolateral prefrontal cortex in schizophrenia revisited. Cereb. Cortex 2000, 10, 1078-1092. [CrossRef] [PubMed]

63. Manoach, D.S.; Gollub, R.L.; Benson, E.S.; Searl, M.M.; Goff, D.C.; Halpern, E.; Saper, C.B.; Rauch, S.L. Schizophrenic subjects show aberrant fMRI activation of dorsolateral prefrontal cortex and basal ganglia during working memory performance. Biol. Psychiatry 2000, 48, 99-109. [CrossRef]

64. Dienel, S.J.; Enwright, J.F., III; Hoftman, G.D.; Lewis, D.A. Markers of glutamate and GABA neurotransmission in the prefrontal cortex of schizophrenia subjects: Disease effects differ across anatomical levels of resolution. Schizophr. Res. 2020, 217, 86-94. [CrossRef]

65. Lahti, A.C.; Holcomb, H.H.; Medoff, D.R.; Tamminga, C.A. Ketamine activates psychosis and alters limbic blood flow in schizophrenia. Neuroreport 1995, 6, 869-872. [CrossRef]

66. Abdallah, C.G.; De Feyter, H.M.; Averill, L.A.; Jiang, L.; Averill, C.L.; Chowdhury, G.M.I.; Purohit, P.; de Graaf, R.A.; Esterlis, I.; Juchem, C.; et al. The effects of ketamine on prefrontal glutamate neurotransmission in healthy and depressed subjects. Neuropsychopharmacology 2018, 43, 2154-2160. [CrossRef]

67. Basar, E.; Schurmann, M.; Basar-Eroglu, C.; Karakas, S. Alpha oscillations in brain functioning: An integrative theory. Int. J. Psychophysiol. 1997, 26, 5-29. [CrossRef]

68. Basar-Eroglu, C.; Basar, E.; Demiralp, T.; Schurmann, M. P300-response: Possible psychophysiological correlates in delta and theta frequency channels. A review. Int. J. Psychophysiol. 1992, 13, 161-179. [CrossRef]

69. Miller, R. Cortico-Hippocampal Interplay and the Representation of Contexts in the Brain; Springer: Berlin, Germany, 1991. 
70. Klimesch, W.; Schimke, H.; Schwaiger, J. Episodic and semantic memory: An analysis in the EEG theta and alpha band. Electroencephalogr. Clin. Neurophysiol. 1994, 91, 428-441. [CrossRef]

71. Basar, E.; Basar-Eroglu, C.; Karakas, S.; Schurmann, M. Are cognitive processes manifested in eventrelated gamma, alpha, theta and delta oscillations in the EEG? Neurosci. Lett. 1999, 259, 165-168. [CrossRef]

72. Catts, V.S.; Lai, Y.L.; Weickert, C.S.; Weickert, T.W.; Catts, S.V. A quantitative review of the postmortem evidence for decreased cortical N-methyl-D-aspartate receptor expression levels in schizophrenia: How can we link molecular abnormalities to mismatch negativity deficits? Biol. Psychology 2016, 116, 57-67. [CrossRef]

73. Sokolov, B.P. Expression of NMDAR1, GluR1, GluR7, and KA1 glutamate receptor mRNAs is decreased in frontal cortex of "neuroleptic-free" schizophrenics: Evidence on reversible up-regulation by typical neuroleptics. J. Neurochem. 1998, 71, 2454-2464. [CrossRef] [PubMed]

74. Catts, V.S.; Derminio, D.S.; Hahn, C.G.; Weickert, C.S. Postsynaptic density levels of the NMDA receptor NR1 subunit and PSD-95 protein in prefrontal cortex from people with schizophrenia. NPJ Schizophr. 2015, 1, 15037. [CrossRef] [PubMed]

75. Gao, X.M.; Sakai, K.; Roberts, R.C.; Conley, R.R.; Dean, B.; Tamminga, C.A. Ionotropic glutamate receptors and expression of N-methyl-D-aspartate receptor subunits in subregions of human hippocampus: Effects of schizophrenia. Am. J. Psychiatry 2000, 157, 1141-1149. [CrossRef]

76. Law, A.J.; Deakin, J.F. Asymmetrical reductions of hippocampal NMDAR1 glutamate receptor mRNA in the psychoses. Neuroreport 2001, 12, 2971-2974. [CrossRef]

77. Akbarian, S.; Sucher, N.J.; Bradley, D.; Tafazzoli, A.; Trinh, D.; Hetrick, W.P.; Potkin, S.G.; Sandman, C.A.; Bunney, W.E., Jr.; Jones, E.G. Selective alterations in gene expression for NMDA receptor subunits in prefrontal cortex of schizophrenics. J. Neurosci. 1996, 16, 19-30. [CrossRef]

78. Weickert, C.S.; Fung, S.J.; Catts, V.S.; Schofield, P.R.; Allen, K.M.; Moore, L.T.; Newell, K.A.; Pellen, D.; Huang, X.F.; Catts, S.V.; et al. Molecular evidence of N-methyl-D-aspartate receptor hypofunction in schizophrenia. Mol. Psychiatry 2013, 18, 1185-1192. [CrossRef]

79. Banerjee, A.; Wang, H.Y.; Borgmann-Winter, K.E.; MacDonald, M.L.; Kaprielian, H.; Stucky, A.; Kvasic, J.; Egbujo, C.; Ray, R.; Talbot, K.; et al. Src kinase as a mediator of convergent molecular abnormalities leading to NMDAR hypoactivity in schizophrenia. Mol. Psychiatry 2015, 20, 1091-1100. [CrossRef]

80. Seeman, P.; Lee, T. Antipsychotic drugs: Direct correlation between clinical potency and presynaptic action on dopamine neurons. Science 1975, 188, 1217-1219. [CrossRef]

81. Creese, I.; Burt, D.R.; Snyder, S.H. Dopamine receptor binding predicts clinical and pharmacological potencies of antischizophrenic drugs. Science 1976, 192, 481-483. [CrossRef]

82. Abi-Dargham, A.; Rodenhiser, J.; Printz, D.; Zea-Ponce, Y.; Gil, R.; Kegeles, L.S.; Weiss, R.; Cooper, T.B.; Mann, J.J.; Van Heertum, R.L.; et al. Increased baseline occupancy of D2 receptors by dopamine in schizophrenia. Proc. Natl. Acad. Sci. USA 2000, 97, 8104-8109. [CrossRef]

83. Vollenweider, F.X.; Vontobel, P.; Oye, I.; Hell, D.; Leenders, K.L. Effects of (S)-ketamine on striatal dopamine: $\mathrm{A}\left[{ }^{11} \mathrm{C}\right]$ raclopride PET study of a model psychosis in humans. J. Psychiatr. Res. 2000, 34, 35-43. [CrossRef]

84. Kristiansen, L.V.; Huerta, I.; Beneyto, M.; Meador-Woodruff, J.H. NMDA receptors and schizophrenia. Curr. Opin. Pharmacol. 2007, 7, 48-55. [CrossRef]

85. Moghaddam, B.; Javitt, D. From revolution to evolution: The glutamate hypothesis of schizophrenia and its implication for treatment. Neuropsychopharmacology 2012, 37, 4-15. [CrossRef]

86. Okabe, S.; Miwa, A.; Okado, H. Alternative splicing of the C-terminal domain regulates cell surface expression of the NMDA receptor NR1 subunit. J. Neurosci. 1999, 19, 7781-7792. [CrossRef]

87. Pauly, T.; Schlicksupp, A.; Neugebauer, R.; Kuhse, J. Synaptic targeting of N-methyl-D-aspartate receptor splice variants is regulated differentially by receptor activity. Neuroscience 2005, 131, 99-111. [CrossRef]

88. Bauer, D.; Gupta, D.; Harotunian, V.; Meador-Woodruff, J.H.; McCullumsmith, R.E. Abnormal expression of glutamate transporter and transporter interacting molecules in prefrontal cortex in elderly patients with schizophrenia. Schizophr. Res. 2008, 104, 108-120. [CrossRef]

89. Kalandadze, A.; Wu, Y.; Fournier, K.; Robinson, M.B. Identification of motifs involved in endoplasmic reticulum retention-forward trafficking of the GLT-1 subtype of glutamate transporter. J. Neurosci. 2004, 24, 5183-5192. [CrossRef]

90. Spangaro, M.; Bosia, M.; Zanoletti, A.; Bechi, M.; Mariachiara, B.; Pirovano, A.; Lorenzi, C.; Bramanti, P.; Smeraldi, E.; Cavallaro, R. Exploring effects of EAAT polymorphisms on cognitive functions in schizophrenia. Pharmacogenomics 2014, 15, 925-932. [CrossRef] 
91. Dietz, A.G.; Goldman, S.A.; Nedergaard, M. Glial cells in schizophrenia: A unified hypothesis. Lancet Psychiatry 2020, 7, 272-281. [CrossRef]

92. Homayoun, H.; Stefani, M.R.; Adams, B.W.; Tamagan, G.D.; Moghaddam, B. Functional interaction between NMDA and mGlu5 receptors: Effects on working memory, instrumental learning, motor behaviors, and dopamine release. Neuropsychopharmacology 2004, 29, 1259-1269. [CrossRef]

93. Lipska, B.K.; Weinberger, D.R. Animal models of schizophrenia. In Schizophrenia; Hirsch, S.R., Weinberger, D.R., Eds.; Blackwell Science: Malden, UK, 2003; pp. 388-402.

94. Sams-Dodd, F. Effect of novel antipsychotic drugs on phencyclidine-induced stereotyped behaviour and social isolation in the rat social interaction test. Behav. Pharmacol. 1997, 8, 196-215.

95. Giros, B.; Jaber, M.; Jones, S.R.; Wightman, R.M.; Caron, M.G. Hyperlocomotion and indifference to cocaine and amphetamine in mice lacking the dopamine transporter. Nature 1996, 379, 606-612. [CrossRef]

96. Jentsch, J.D.; Tran, A.; Taylor, J.R.; Roth, R.H. Prefrontal cortical involvement in phencyclidine-induced activation of the mesolimbic dopamine system: Behavioral and neurochemical evidence. Psychopharmacology (Berlin) 1998, 138, 89-95. [CrossRef]

97. Bakshi, V.P.; Tricklebank, M.; Neijt, H.C.; Lehmann-Masten, V.; Geyer, M.A. Disruption of prepulse inhibition and increases in locomotor activity by competitive N-methyl-D-aspartate receptor antagonists in rats. J. Pharmacol. Exp. Ther. 1999, 288, 643-652.

98. Broberg, B.V.; Oranje, B.; Glenthøj, B.Y.; Fejgin, K.; Plath, N.; Bastlund, J.F. Assessment of auditory sensory processing in a neurodevelopmental animal model of schizophrenia-gating of auditory-evoked potentials and prepulse inhibition. Behav. Brain Res. 2010, 213, 142-147. [CrossRef]

99. Suzuki, Y.; Jodo, E.; Takeuchi, S.; Niwa, S.; Kayama, Y. Acute administration of phencyclidine induces tonic activation of medial prefrontal cortex neurons in freely moving rats. Neuroscience 2002, 114, 769-779. [CrossRef]

100. Jackson, M.E.; Homayoun, H.; Moghaddam, B. NMDA receptor hypofunction produces concomitant firing rate potentiation and burst activity reduction in the prefrontal cortex. Proc. Natl. Acad. Sci. USA 2004, 101, 8467-8472. [CrossRef]

101. Kargieman, L.; Santana, N.; Mengod, G.; Celada, P.; Artigas, F. Antipsychotic drugs reverse the disruption in prefrontal cortex function produced by NMDA receptor blockade with phencyclidine. Proc. Natl. Acad. Sci. USA 2007, 104, 14843-14848. [CrossRef]

102. López-Gil, X.; Jiménez-Sánchez, L.; Romón, T.; Campa, L.; Artigas, F.; Adell, A. Importance of inter-hemispheric prefrontal connection in the effects of non-competitive NMDA receptor antagonists. Int. J. Neuropsychopharmacol. 2012, 15, 945-956. [CrossRef]

103. Lladó-Pelfort, L.; Celada, P.; Riga, M.S.; Troyano-Rodríguez, E.; Santana, N.; Artigas, F. Effects of hallucinogens on neuronal activity. Curr. Top. Behav. Neurosci. 2018, 36, 75-105.

104. Moghaddam, B.; Adams, B.; Verma, A.; Daly, D. Activation of glutamatergic neurotransmission by ketamine: A novel step in the pathway from NMDA receptor blockade to dopaminergic and cognitive disruptions associated with the prefrontal cortex. J. Neurosci. 1997, 17, 2921-2927. [CrossRef]

105. Adams, B.W.; Moghaddam, B. Effect of clozapine, haloperidol, or M100907 on phencyclidine-activated glutamate efflux in the prefrontal cortex. Biol. Psychiatry 2001, 50, 750-757. [CrossRef]

106. Lorrain, D.S.; Baccei, C.S.; Bristow, L.J.; Anderson, J.J.; Varney, M.A. Effects of ketamine and $\mathrm{N}$-methyl-D-aspartate on glutamate and dopamine release in the rat prefrontal cortex: Modulation by a group II selective metabotropic glutamate receptor agonist LY379268. Neuroscience 2003, 117, 697-706. [CrossRef]

107. Moghaddam, B.; Adams, B.W. Reversal of phencyclidine effects by a group II metabotropic glutamate receptor agonist in rats. Science 1998, 281, 1349-1352. [CrossRef]

108. Mathé, J.M.; Nomikos, G.G.; Blakeman, K.H.; Svensson, T.H. Differential actions of dizocilpine (MK-801) on the mesolimbic and mesocortical dopamine systems: Role of neuronal activity. Neuropharmacology 1999, 38, 121-128. [CrossRef]

109. Schmidt, C.J.; Fadayel, G.M. Regional effects of MK-801 on dopamine release: Effects of competitive NMDA or 5-HT $\mathrm{H}_{2 \mathrm{~A}}$ receptor blockade. J. Pharmacol. Exp. Ther. 1996, 277, 1541-1549.

110. Martin, P.; Carlsson, M.L.; Hjorth, S. Systemic PCP treatment elevates brain extracellular 5-HT: A microdialysis study in awake rats. Neuroreport 1998, 9, 2985-2988. [CrossRef] 
111. Millan, M.J.; Brocco, M.; Gobert, A.; Joly, F.; Bervoets, K.; Rivet, J.; Newman-Tancredi, A.; Audinot, V.; Maurel, S. Contrasting mechanisms of action and sensitivity to antipsychotics of phencyclidine versus amphetamine: Importance of nucleus accumbens 5- $\mathrm{HT}_{2 \mathrm{~A}}$ sites for PCP-induced locomotion in the rat. Eur. J. Neurosci. 1999, 11, 4419-4432. [CrossRef]

112. Amargós-Bosch, M.; López-Gil, X.; Artigas, F.; Adell, A. Clozapine and olanzapine, but not haloperidol, suppress serotonin efflux in the medial prefrontal cortex elicited by phencyclidine and ketamine. Int. J. Neuropsychopharmacol. 2006, 9, 565-573. [CrossRef]

113. Schiffer, W.K.; Gerasimov, M.; Hofmann, L.; Marsteller, D.; Ashby, C.R.; Brodie, J.D.; Alexoff, D.L.; Dewey, S.L. Gamma vinyl-GABA differentially modulates NMDA antagonist-induced increases in mesocortical versus mesolimbic DA transmission. Neuropsychopharmacology 2001, 25, 704-712. [CrossRef]

114. Nelson, C.L.; Burk, J.A.; Bruno, J.P.; Sarter, M. Effects of acute and repeated systemic administration of ketamine on prefrontal acetylcholine release and sustained attention performance in rats. Psychopharmacology (Berl) 2002, 161, 168-179. [CrossRef]

115. Jiménez-Sánchez, L.; Castañé, A.; Pérez-Caballero, L.; Grifoll-Escoda, M.; López-Gil, X.; Campa, L.; Galofré, M.; Berrocoso, E.; Adell, A. Activation of AMPA receptors mediates the antidepressant action of deep brain stimulation of the infralimbic prefrontal cortex. Cereb. Cortex 2016, 26, 2778-2789. [CrossRef]

116. López-Gil, X.; Jiménez-Sánchez, L.; Campa, L.; Castro, E.; Frago, C.; Adell, A. Role of serotonin and noradrenaline in the rapid antidepressant action of ketamine. ACS Chem. Neurosci. 2019, 10, 3318-3326. [CrossRef]

117. Krystal, J.H.; D'Souza, D.C.; Mathalon, D.; Perry, E.; Belger, A.; Hoffman, R. NMDA receptor antagonist effects, cortical glutamatergic function, and schizophrenia: Toward a paradigm shift in medication development. Psychopharmacology (Berl) 2003, 169, 215-233. [CrossRef]

118. Nyíri, G.; Stephenson, F.A.; Freund, T.F.; Somogyi, P. Large variability in synaptic N-methyl-D-aspartate receptor density on interneurons and a comparison with pyramidal-cell spines in the rat hippocampus. Neuroscience 2003, 119, 347-363. [CrossRef]

119. Freund, T.F.; Katona, I. Perisomatic inhibition. Neuron 2007, 56, 33-42. [CrossRef]

120. Razoux, F.; Garcia, R.; Lena, I. Ketamine, at a dose that disrupts motor behavior and latent inhibition, enhances prefrontal cortex synaptic efficacy and glutamate release in the nucleus accumbens. Neuropsychopharmacology 2007, 32, 719-727. [CrossRef]

121. Kim, S.H.; Price, M.T.; Olney, J.W.; Farber, N.B. Excessive cerebrocortical release of acetylcholine induced by NMDA antagonists is reduced by GABAergic and alpha2-adrenergic agonists. Mol. Psychiatry 1999, 4, 344-352. [CrossRef]

122. Hutson, P.H.; Hogg, J.E. Effects of and interactions between antagonists for different sites on the NMDA receptor complex on hippocampal and striatal acetylcholine efflux in vivo. Eur. J. Pharmacol. 1996, 295, 45-52. [CrossRef]

123. Yan, Q.S.; Reith, M.E.; Jobe, P.C.; Dailey, J.W. Dizocilpine (MK-801) increases not only dopamine but also serotonin and norepinephrine transmissions in the nucleus accumbens as measured by microdialysis in freely moving rats. Brain Res. 1997, 765, 149-158. [CrossRef]

124. Lorrain, D.S.; Schaffhauser, H.; Campbell, U.C.; Baccei, C.S.; Correa, L.D.; Rowe, B.; Rodriguez, D.E.; Anderson, J.J.; Varney, M.A.; Pinkerton, A.B.; et al. Group II mGlu receptor activation suppresses norepinephrine release in the ventral hippocampus and locomotor responses to acute ketamine challenge. Neuropsychopharmacology 2003, 28, 1622-1632. [CrossRef] [PubMed]

125. Swanson, C.J.; Schoepp, D.D. A role for noradrenergic transmission in the actions of phencyclidine and the antipsychotic and antistress effects of mGlu2/3 receptor agonists. Ann. N. Y. Acad. Sci. 2003, 1003, 309-317. [CrossRef] [PubMed]

126. Whitton, P.S.; Maione, S.; Biggs, C.S.; Fowler, L.J. N-methyl-d-aspartate receptors modulate extracellular dopamine concentration and metabolism in rat hippocampus and striatum in vivo. Brain Res. 1994, 635, 312-316. [CrossRef]

127. Kretschmer, B.D. NMDA receptor antagonist-induced dopamine release in the ventral pallidum does not correlate with motor activation. Brain Res. 2000, 859, 147-156. [CrossRef]

128. Greenslade, R.G.; Mitchell, S.N. Selective action of (-)-2-oxa-4-aminobicyclo [3.1.0] hexane-4,6-dicarboxylate (LY379268), a group II metabotropic glutamate receptor agonist, on basal and phencyclidine-induced dopamine release in the nucleus accumbens shell. Neuropharmacology 2004, 47, 1-8. [CrossRef] 
129. Fitzgerald, P.J.; Watson, B.O. In vivo electrophysiological recordings of the effects of antidepressant drugs. Exp. Brain Res. 2019, 237, 1593-1614. [CrossRef]

130. Pitkänen, M.; Sirviö, J.; Ylinen, A.; Koivisto, E.; Riekkinen, P. Effects of NMDA receptor modulation on hippocampal type 2 theta activity in rats. Gen. Pharmacol. 1995, 26, 1065-1070. [CrossRef]

131. Lazarewicz, M.T.; Ehrlichman, R.S.; Maxwell, C.R.; Gandal, M.J.; Finkel, L.H.; Siegel, S.J. Ketamine modulates theta and gamma oscillations. J. Cogn. Neurosci. 2010, 22, 1452-1464. [CrossRef]

132. Troyano-Rodriguez, E.; Lladó-Pelfort, L.; Santana, N.; Teruel-Martí, V.; Celada, P.; Artigas, F. Phencyclidine inhibits the activity of thalamic reticular gamma-aminobutyric acidergic neurons in rat brain. Biol. Psychiatry 2014, 76, 937-945. [CrossRef]

133. Adell, A.; Jiménez-Sánchez, L.; López-Gil, X.; Romón, T. Is the acute NMDA receptor hypofunction a valid model of schizophrenia? Schizophr. Bull. 2012, 38, 9-14. [CrossRef] [PubMed]

134. Egerton, A.; Reid, L.; McGregor, S.; Cochran, S.M.; Morris, B.J.; Pratt, J.A. Subchronic and chronic PCP treatment produces temporally distinct deficits in attentional set shifting and prepulse inhibition in rats. Psychopharmacology (Berl) 2008, 198, 37-49. [CrossRef]

135. Jentsch, J.D.; Roth, R.H. The neuropsychopharmacology of phencyclidine: From NMDA receptor hypofunction to the dopamine hypothesis of schizophrenia. Neuropsychopharmacology 1999, 20, 201-225. [CrossRef]

136. Neill, J.C.; Harte, M.K.; Haddad, P.M.; Lydall, E.S.; Dwyer, D.M. Acute and chronic effects of NMDA receptor antagonists in rodents, relevance to negative symptoms of schizophrenia: A translational link to humans. Eur. Neuropsychopharmacol. 2014, 24, 822-823. [CrossRef] [PubMed]

137. Spielewoy, C.; Markou, A. Withdrawal from chronic phencyclidine treatment induces long-lasting depression in brain reward function. Neuropsychopharmacology 2003, 28, 1106-1116. [CrossRef] [PubMed]

138. Thomson, D.M.; McVie, A.; Morris, B.J.; Pratt, J.A. Dissociation of acute and chronic intermittent phencyclidine-induced performance deficits in the 5-choice serial reaction time task: Influence of clozapine. Psychopharmacology (Berl) 2011, 213, 681-695. [CrossRef]

139. Mouri, A.; Koseki, T.; Narusawa, S.; Niwa, M.; Mamiya, T.; Kano, S.; Sawa, A.; Nabeshima, T. Mouse strain differences in phencyclidine-induced behavioural changes. Int. J. Neuropsychopharmacol. 2012, 15, 767-779. [CrossRef]

140. Xu, X.; Domino, E.F. Genetic differences in the locomotor response to single and daily doses of phencyclidine in inbred mouse strains. Behav. Pharmacol. 1994, 5, 623-629. [CrossRef]

141. Castañé, A.; Santana, N.; Artigas, F. PCP-based mice models of schizophrenia: Differential behavioral, neurochemical and cellular effects of acute and subchronic treatments. Psychopharmacology (Berl) 2015, 232, 4085-4097. [CrossRef]

142. Kondziella, D.; Brenner, E.; Eyjolfsson, E.M.; Markinhuhta, K.R.; Carlsson, M.L.; Sonnewald, U. Glial-neuronal interactions are impaired in the schizophrenia model of repeated MK801 exposure. Neuropsychopharmacology 2006, 31, 1880-1887. [CrossRef]

143. Karlsson, R.M.; Tanaka, K.; Heilig, M.; Holmes, A. Loss of glial glutamate and aspartate transporter (excitatory amino acid transporter 1) causes locomotor hyperactivity and exaggerated responses to psychotomimetics: Rescue by haloperidol and metabotropic glutamate 2/3 agonist. Biol. Psychiatry 2008, 64, 810-814. [CrossRef] [PubMed]

144. Deutsch, S.I.; Mastropaolo, J.; Schwartz, B.L.; Rosse, R.B.; Morihisa, J.M. A "glutamatergic hypothesis" of schizophrenia. Rationale for pharmacotherapy with glycine. Clin. Neuropharmacol. 1989, 12, 1-13. [CrossRef] [PubMed]

145. Javitt, D.C.; Zylberman, I.; Zukin, S.R.; Heresco-Levy, U.; Lindenmayer, J.P. Amelioration of negative symptoms in schizophrenia by glycine. Am. J. Psychiatry 1994, 151, 1234-1236.

146. Heresco-Levy, U.; Javitt, D.C.; Ermilov, M.; Mordel, C.; Horowitz, A.; Kelly, D. Double-blind, placebo-controlled, crossover trial of glycine adjuvant therapy for treatment-resistant schizophrenia. Br. J. Psychiatry 1996, 169, 610-617. [CrossRef]

147. Buchanan, R.W.; Javitt, D.C.; Marder, S.R.; Schooler, N.R.; Gold, J.M.; McMahon, R.P.; Heresco-Levy, U.; Carpenter, W.T. The Cognitive and Negative Symptoms in Schizophrenia Trial (CONSIST): The efficacy of glutamatergic agents for negative symptoms and cognitive impairments. Am. J. Psychiatry 2007, 164, 1593-1602. [CrossRef] 
148. Tsai, G.; Yang, P.; Chung, L.C.; Lange, N.; Coyle, J.T. D-serine added to antipsychotics for the treatment of schizophrenia. Biol. Psychiatry 1998, 44, 1081-1089. [CrossRef]

149. Tsai, G.E.; Yang, P.; Chung, L.C.; Tsai, I.C.; Tsai, C.W.; Coyle, J.T. D-serine added to clozapine for the treatment of schizophrenia. Am. J. Psychiatry 1999, 156, 1822-1825.

150. Heresco-Levy, U.; Javitt, D.C.; Ebstein, R.; Vass, A.; Lichtenberg, P.; Bar, G.; Catinari, S.; Ermilov, M. D-serine efficacy as add-on pharmacotherapy to risperidone and olanzapine for treatment-refractory schizophrenia. Biol. Psychiatry 2005, 57, 577-585. [CrossRef]

151. van Berckel, B.N.; Hijman, R.; van der Linden, J.A.; Westenberg, H.G.; van Ree, J.M.; Kahn, R.S. Efficacy and tolerance of D-cycloserine in drug-free schizophrenic patients. Biol. Psychiatry 1996, 40, 1298-1300. [CrossRef]

152. Heresco-Levy, U.; Javitt, D.C.; Ermilov, M.; Silipo, G.; Shimoni, J. Double-blind, placebo-controlled, crossover trial of D-cycloserine adjuvant therapy for treatment-resistant schizophrenia. Int. J. Neuropsychopharmacol. 1998, 1, 131-135. [CrossRef]

153. Heresco-Levy, U.; Ermilov, M.; Shimoni, J.; Shapira, B.; Silipo, G.; Javitt, D.C. Placebo-controlled trial of D-cycloserine added to conventional neuroleptics, olanzapine, or risperidone in schizophrenia. Am. J. Psychiatry 2002, 159, 480-482. [CrossRef] [PubMed]

154. Duncan, E.J.; Szilagyi, S.; Schwartz, M.P.; Bugarski-Kirola, D.; Kunzova, A.; Negi, S.; Stephanides, M.; Efferen, T.R.; Angrist, B.; Peselow, E.; et al. Effects of D-cycloserine on negative symptoms in schizophrenia. Schizophr. Res. 2004, 71, 239-248. [CrossRef]

155. Goff, D.C.; Herz, L.; Posever, T.; Shih, V.; Tsai, G.; Henderson, D.C.; Freudenreich, O.; Evins, A.E.; Yovel, I.; Zhang, H.; et al. A six-month, placebo-controlled trial of d-cycloserine co-administered with conventional antipsychotics in schizophrenia patients. Psychopharmacology (Berl) 2005, 179, 144-150. [CrossRef]

156. Harvey, R.J.; Yee, B.K. Glycine transporters as novel therapeutic targets in schizophrenia, alcohol dependence and pain. Nat. Rev. Drug Discov. 2013, 12, 866-885. [CrossRef] [PubMed]

157. Lin, C.Y.; Liang, S.Y.; Chang, Y.C.; Ting, S.Y.; Kao, C.L.; Wu, Y.H.; Tsai, G.E.; Lane, H.Y. Adjunctive sarcosine plus benzoate improved cognitive function in chronic schizophrenia patients with constant clinical symptoms: A randomised, double-blind, placebo-controlled trial. World J. Biol. Psychiatry 2017, 18, 357-368. [CrossRef]

158. Fone, K.C.F.; Watson, D.J.G.; Billiras, R.I.; Sicard, D.I.; Dekeyne, A.; Rivet, J.M.; Gobert, A.; Millan, M.J. Comparative pro-cognitive and neurochemical profiles of glycine modulatory site agonists and glycine reuptake inhibitors in the rat: Potential relevance to cognitive dysfunction and its management. Mol. Neurobiol. 2020, 57, 2144-2166. [CrossRef]

159. Lin, C.H.; Chen, Y.M.; Lane, H.Y. Novel treatment for the most resistant schizophrenia: Dual activation of NMDA receptor and antioxidant. Curr. Drug Targets 2020, 21, 610-615. [CrossRef]

160. Kapur, S.; Zipursky, R.; Jones, C.; Remington, G.; Houle, S. Relationship between dopamine D2 occupancy, clinical response, and side effects: A double-blind PET study of first-episode schizophrenia. Am. J. Psychiatry 2000, 157, 514-520. [CrossRef]

161. Newcomer, J.W. Second-generation (atypical) antipsychotics and metabolic effects: A comprehensive literature review. CNS Drugs 2005, 19, 1-93. [CrossRef]

162. López-Gil, X.; Artigas, F.; Adell, A. Role of different monoamine receptors controlling MK-801-induced release of serotonin and glutamate in the medial prefrontal cortex: Relevance for antipsychotic action. Int. J. Neuropsychopharmacol. 2009, 12, 487-499. [CrossRef]

163. López-Gil, X.; Artigas, F.; Adell, A. Unraveling monoamine receptors involved in the action of typical and atypical antipsychotics on glutamatergic and serotonergic transmission in prefrontal cortex. Curr. Pharm. Des. 2010, 16, 502-515. [CrossRef] [PubMed]

164. Carli, M.; Baviera, M.; Invernizzi, R.W.; Balducci, C. Dissociable contribution of 5-HT $1 \mathrm{~A}$ and 5-HT $2 \mathrm{~A}$ receptors in the medial prefrontal cortex to different aspects of executive control such as impulsivity and compulsive perseveration in rats. Neuropsychopharmacology 2006, 31, 757-767. [CrossRef] [PubMed]

165. Zhang, C.; Li, Z.; Wu, Z.; Chen, J.; Wang, Z.; Peng, D.; Hong, W.; Yuan, C.; Wang, Z.; Yu, S.; et al. A study of $\mathrm{N}$-methyl-D-aspartate receptor gene (GRIN2B) variants as predictors of treatment-resistant major depression. Psychopharmacology (Berl) 2014, 231, 685-693. [CrossRef] [PubMed]

166. Niciu, M.J.; Ionescu, D.F.; Richards, E.M.; Zarate, C.A.J. Glutamate and its receptors in the pathophysiology and treatment of major depressive disorder. J. Neural Transm. 2014, 121, 907-924. [CrossRef] 
167. Kaut, O.; Schmitt, I.; Hofmann, A.; Hoffmann, P.; Schlaepfer, T.E.; Wüllner, U.; Hurlemann, R. Aberrant NMDA receptor DNA methylation detected by epigenome-wide analysis of hippocampus and prefrontal cortex in major depression. Eur. Arch. Psychiatry Clin. Neurosci. 2015, 265, 331-341. [CrossRef]

168. Marsden, W.N. Stressor-induced NMDAR dysfunction as a unifying hypothesis of the aetiology, pathogenesis and comorbidity of clinical depression. Med. Hypotheses 2011, 77, 508-528. [CrossRef]

169. Berman, R.M.; Cappiello, A.; Anand, A.; Oren, D.A.; Heninger, G.R.; Charney, D.S.; Krystal, J.H. Antidepressant effects of ketamine in depressed patients. Biol. Psychiatry 2000, 47, 351-354. [CrossRef]

170. Zarate, C.A.J.; Singh, J.B.; Carlson, P.J.; Brutsche, N.E.; Ameli, R.; Luckenbaugh, D.A.; Charney, D.S.; Manji, H.K. A randomized trial of an N-methyl-D-aspartate antagonist in treatment-resistant major depression. Arch. Gen. Psychiatry 2006, 63, 856-864. [CrossRef]

171. Jaso, B.A.; Niciu, M.J.; Iadarola, N.D.; Lally, N.; Richards, E.M.; Park, M.; Ballard, E.D.; Nugent, A.C.; Machado-Vieira, R.; Zarate, C.A.J. Therapeutic modulation of glutamate receptors in major depressive disorder. Curr. Neuropharmacol. 2017, 15, 57-70. [CrossRef]

172. Paul, I.A.; Nowak, G.; Layer, R.T.; Popik, P.; Skolnick, P. Adaptation of the NMDA receptor complex following chronic antidepressant treatments. J. Pharmacol. Ther. 1994, 269, 95-102.

173. Nowak, G.; Li, Y.; Paul, I.A. Adaptation of cortical but not hippocampal NMDA receptors after chronic citalopram treatment. Eur. J. Pharmacol. 1996, 295, 75-85. [CrossRef]

174. Skolnick, P.; Popik, P.; Trullas, R. Glutamate-based antidepressants: 20 years on. Trends Pharmacol. Sci. 2009, 30, 563-569. [CrossRef] [PubMed]

175. Mathews, D.C.; Henter, I.D.; Zarate, C.A. Targeting the glutamatergic system to treat major depressive disorder: Rationale and progress to date. Drugs 2012, 72, 1313-1333. [CrossRef]

176. Ghasemi, M.; Phillips, C.; Trillo, L.; De Miguel, Z.; Das, D.; Salehi, A. The role of NMDA receptors in the pathophysiology and treatment of mood disorders. Neurosci. Biobehav. Rev. 2014, 47, 336-358. [CrossRef]

177. Naughton, M.; Clarke, G.; O’Leary, O.F.; Cryan, J.F.; Dinan, T.G. A review of ketamine in affective disorders: Current evidence of clinical efficacy, limitations of use and pre-clinical evidence on proposed mechanisms of action. J. Affect. Disord. 2014, 156, 24-35. [CrossRef] [PubMed]

178. Deutschenbaur, L.; Beck, J.; Kiyhankhadiv, A.; Mühlhauser, M.; Borgwardt, S.; Walter, M.; Hasler, G.; Sollberger, D.; Lang, U.E. Role of calcium, glutamate and NMDA in major depression and therapeutic application. Prog. Neuropsychopharmacol. Biol. Psychiatry 2016, 64, 325-333. [CrossRef] [PubMed]

179. Feyissa, A.M.; Chandran, A.; Stockmeier, C.A.; Karolewicz, B. Reduced levels of NR2A and NR2B subunits of NMDA receptor and PSD-95 in the prefrontal cortex in major depression. Prog. Neuropsychopharmacol. Biol. Psychiatry 2009, 33, 70-75. [CrossRef] [PubMed]

180. Beneyto, M.; Kristiansen, L.V.; Oni-Orisan, A.; McCullumsmith, R.E.; Meador-Woodruff, J.H. Abnormal glutamate receptor expression in the medial temporal lobe in schizophrenia and mood disorders. Neuropsychopharmacology 2007, 32, 1888-1902. [CrossRef]

181. Karolewicz, B.; Szebeni, K.; Gilmore, T.; Maciag, D.; Stockmeier, C.A.; Ordway, G.A. Elevated levels of NR2A and PSD-95 in the lateral amygdala in depression. Int. J. Neuropsychopharmacol. 2009, 12, 143-153. [CrossRef]

182. Rodríguez-Muñoz, M.; Sánchez-Blázquez, P.; Callado, L.F.; Meana, J.J.; Garzón-Niño, J. Schizophrenia and depression, two poles of endocannabinoid system deregulation. Transl. Psychiatry 2017, 7, 1291. [CrossRef]

183. Karolewicz, B.; Stockmeier, C.; Ordway, G.A. Elevated levels of the NR2C subunit of the NMDA receptor in the locus coeruleus in depression. Neuropsychopharmacology 2005, 30, 1557-1567. [CrossRef] [PubMed]

184. Underwood, M.D.; Bakalian, M.J.; Johnson, V.L.; Kassir, S.A.; Ellis, S.P.; Mann, J.J.; Arango, V. Less NMDA receptor binding in dorsolateral prefrontal cortex and anterior cingulate cortex associated with reported early life adversity but not suicide. Int. J. Neuropsychopharmacol. 2020. [CrossRef] [PubMed]

185. McCarthy, D.J.; Alexander, R.; Smith, M.A.; Pathak, S.; Kanes, S.; Lee, C.M.; Sanacora, G. Glutamate-based depression GBD. Med. Hypotheses 2012, 78, 675-681. [CrossRef]

186. Chandley, M.J.; Szebeni, A.; Szebeni, K.; Crawford, J.D.; Stockmeier, C.A.; Turecki, G.; Kostrzewa, R.M.; Ordway, G.A. Elevated gene expression of glutamate receptors in noradrenergic neurons from the locus coeruleus in major depression. Int. J. Neuropsychopharmacol. 2014, 17, 1569-1578. [CrossRef] [PubMed]

187. Gray, A.L.; Hyde, T.M.; Deep-Soboslay, A.; Kleinman, J.E.; Sodhi, M.S. Sex differences in glutamate receptor gene expression in major depression and suicide. Mol. Psychiatry 2015, 20, 1057-1068. [CrossRef] 
188. Lin, E.; Kuo, P.H.; Liu, Y.L.; Yu, Y.W.; Yang, A.C.; Tsai, S.J. A deep learning approach for predicting antidepressant response in major depression using clinical and genetic biomarkers. Front. Psychiatry 2018, 9, 290. [CrossRef]

189. Weder, N.; Zhang, H.; Jensen, K.; Yang, B.Z.; Simen, A.; Jackowski, A.; Lipschitz, D.; Douglas-Palumberi, H.; Ge, M.; Perepletchikova, F.; et al. Child abuse, depression, and methylation in genes involved with stress, neural plasticity, and brain circuitry. J. Am. Acad. Child Adolesc. Psychiatry 2014, 53, 417-424. [CrossRef]

190. Calabrese, F.; Guidotti, G.; Molteni, R.; Racagni, G.; Mancini, M.; Riva, M.A. Stress-induced changes of hippocampal NMDA receptors: Modulation by duloxetine treatment. PLoS ONE 2012, 7, e37916. [CrossRef]

191. Wang, Q.; Jie, W.; Liu, J.H.; Yang, J.M.; Gao, T.M. An astroglial basis of major depressive disorder? An overview. Glia 2017, 65, 1227-1250. [CrossRef]

192. Czéh, B.; Nagy, S.A. Clinical findings documenting cellular and molecular abnormalities of glia in depressive disorders. Front. Mol. Neurosci. 2018, 11, 56. [CrossRef]

193. Ongür, D.; Drevets, W.C.; Price, J.L. Glial reduction in the subgenual prefrontal cortex in mood disorders. Proc. Natl. Acad. Sci. USA 1998, 95, 13290-13295. [CrossRef] [PubMed]

194. Cotter, D.; Mackay, D.; Chana, G.; Beasley, C.; Landau, S.; Everall, I.P. Reduced neuronal size and glial cell density in area 9 of the dorsolateral prefrontal cortex in subjects with major depressive disorder. Cereb. Cortex 2002, 12, 386-394. [CrossRef]

195. Rajkowska, G.; Stockmeier, C.A. Astrocyte pathology in major depressive disorder: Insights from human postmortem brain tissue. Curr. Drug Targets 2013, 14, 1225-1236. [CrossRef] [PubMed]

196. Cobb, J.A.; Simpson, J.; Mahajan, G.J.; Overholser, J.C.; Jurjus, G.J.; Dieter, L.; Herbst, N.; May, W.; Rajkowska, G.; Stockmeier, C.A. Hippocampal volume and total cell numbers in major depressive disorder. J. Psychiatr. Res. 2013, 47, 299-306. [CrossRef] [PubMed]

197. Miguel-Hidalgo, J.J.; Baucom, C.; Dilley, G.; Overholser, J.C.; Meltzer, H.Y.; Stockmeier, C.A.; Rajkowska, G. Glial fibrillary acidic protein immunoreactivity in the prefrontal cortex distinguishes younger from older adults in major depressive disorder. Biol. Psychiatry 2000, 48, 861-873. [CrossRef]

198. Moghaddam, B. Stress preferentially increases extraneuronal levels of excitatory amino acids in the prefrontal cortex: Comparison to hippocampus and basal ganglia. J. Neurochem. 1993, 60, 1650-1657. [CrossRef]

199. Bartanusz, V. Stress-induced changes in messenger RNA levels of $N$-methyl-d-aspartate and AMPA receptor subunits in selected regions of the rat hippocampus and hypothalamus. Neuroscience 1995, 66, 247-252. [CrossRef]

200. Fitzgerald, L.W.; Ortiz, J.; Hamedani, A.G.; Nestler, E.J. Drugs of abuse and stress increase the expression of GluR1 and NMDAR1 glutamate receptor subunits in the rat ventral tegmental area: Common adaptations among cross-sensitizing agents. J. Neurosci. 1996, 16, 274-282. [CrossRef]

201. Shepard, R.; Page, C.E.; Coutellier, L. Sensitivity of the prefrontal GABAergic system to chronic stress in male and female mice: Relevance for sex differences in stress-related disorders. Neuroscience 2016, 332, 1-12. [CrossRef]

202. Page, C.E.; Shepard, R.; Heslin, K.; Coutellier, L. Prefrontal parvalbumin cells are sensitive to stress and mediate anxiety-related behaviors in female mice. Sci. Rep. 2019, 9, 19772. [CrossRef]

203. Ji, M.H.; Zhang, L.; Mao, M.J.; Zhang, H.; Yang, J.J.; Qiu, L.L. Overinhibition mediated by parvalbumin interneurons might contribute to depression-like behavior and working memory impairment induced by lipopolysaccharide challenge. Behav. Brain Res. 2020, 383, 112509. [CrossRef] [PubMed]

204. Fogaça, M.V.; Duman, R.S. Cortical GABAergic dysfunction in stress and depression: New insights for therapeutic interventions. Front. Cell. Neurosci. 2019, 13, 87. [CrossRef] [PubMed]

205. Masrour, F.F.; Peeri, M.; Azarbayjani, M.A.; Hosseini, M.J. Voluntary exercise during adolescence mitigated negative the effects of maternal separation stress on the depressive-like behaviors of adult male rats: Role of NMDA receptors. Neurochem. Res. 2018, 43, 1067-1074. [CrossRef] [PubMed]

206. Sathyanesan, M.; Haiar, J.M.; Watt, M.J.; Newton, S.S. Restraint stress differentially regulates inflammation and glutamate receptor gene expression in the hippocampus of C57BL/6 and BALB/c mice. Stress 2017, 20, 197-204. [CrossRef] [PubMed]

207. Pacheco, A.; Aguayo, F.I.; Aliaga, E.; Muñoz, M.; García-Rojo, G.; Olave, F.A.; Parra-Fiedler, N.A.; García-Pérez, A.; Tejos-Bravo, M.; Rojas, P.S.; et al. Chronic stress triggers expression of immediate early genes and differentially affects the expression of AMPA and NMDA subunits in dorsal and ventral hippocampus of rats. Front. Mol. Neurosci. 2017, 10, 244. [CrossRef] 
208. Weiland, N.G.; Orchinik, M.; Tanapat, P. Chronic corticosterone treatment induces parallel changes in N-methyl-D-aspartate receptor subunit messenger RNA levels and antagonist binding sites in the hippocampus. Neuroscience 1997, 78, 653-662. [CrossRef]

209. Webster, H.H.; Flores, G.; Marcotte, E.R.; Cecyre, D.; Quirion, R.; Srivastava, L.K. Olfactory bulbectomy alters NMDA receptor levels in the rat prefrontal cortex. Synapse 2000, 37, 159-162. [CrossRef]

210. Ho, Y.J.; Liu, T.M.; Tai, M.Y.; Wen, Z.H.; Chow, R.S.S.; Tsai, Y.F.; Wong, C.S. Effects of olfactory bulbectomy on NMDA receptor density in the rat brain: [3H] MK-801 binding assay. Brain Res. 2001, 900, 214-218. [CrossRef]

211. Dong, B.E.; Chen, H.; Sakata, K. BDNF deficiency and enriched environment treatment affect neurotransmitter gene expression differently across ages. J. Neurochem. 2020. [CrossRef]

212. Boyce-Rustay, J.M.; Holmes, A. Genetic inactivation of the NMDA receptor NR2A subunit has anxiolyticand antidepressant-like effects in mice. Neuropsychopharmacology 2006, 31, 2405-2414. [CrossRef]

213. Salimando, G.J.; Hyun, M.; Boyt, K.M.; Winder, D.G. BNST GluN2D-containing NMDA receptors influence anxiety- and depressive-like behaviors and modulate cell-specific excitatory/inhibitory synaptic balance. J. Neurosci. 2020, 40, 3949-3968. [CrossRef] [PubMed]

214. Forrest, D.; Yuzaki, M.; Soares, H.D.; Ng, L.; Luk, D.C.; Sheng, M.; Stewart, C.L.; Morgan, J.I.; Connor, J.A.; Curran, T. Targeted disruption of NMDA receptor 1 gene abolishes NMDA response and results in neonatal death. Neuron 1994, 13, 325-338. [CrossRef]

215. Kutsuwada, T.; Sakimura, K.; Manabe, T.; Takayama, C.; Katakura, N.; Kushiya, E.; Natsume, R.; Watanabe, M.; Inoue, Y.; Yagi, T.; et al. Impairment of suckling response, trigeminal neuronal pattern formation, and hippocampal LTD in NMDA receptor epsilon 2 subunit mutant mice. Neuron 1996, 16, 333-344. [CrossRef]

216. Montalvo-Ortiz, J.L.; Bordner, K.A.; Carlyle, B.C.; Gelernter, J.; Simen, A.A.; Kaufman, J. The role of genes involved in stress, neural plasticity, and brain circuitry in depressive phenotypes: Convergent findings in a mouse model of neglect. Behav. Brain Res. 2016, 315, 71-74. [CrossRef]

217. Tordera, R.M.; Garcia-García, A.L.; Elizalde, N.; Segura, V.; Aso, E.; Venzala, E.; Ramírez, M.J.; Del Rio, J. Chronic stress and impaired glutamate function elicit a depressive-like phenotype and common changes in gene expression in the mouse frontal cortex. Eur. Neuropsychopharmacol. 2011, 21, 23-32. [CrossRef] [PubMed]

218. Sanacora, G.; Banasr, M. From pathophysiology to novel antidepressant drugs: Glial contributions to the pathology and treatment of mood disorders. Biol. Psychiatry 2013, 73, 1172-1179. [CrossRef]

219. Banasr, M.; Chowdhury, G.M.; Terwilliger, R.; Newton, S.S.; Duman, R.S.; Behar, K.L.; Sanacora, G. Glial pathology in an animal model of depression: Reversal of stress-induced cellular, metabolic and behavioral deficits by the glutamate-modulating drug riluzole. Mol. Psychiatry 2010, 15, 501-511. [CrossRef]

220. Gong, Y.; Sun, X.L.; Wu, F.F.; Su, C.J.; Ding, J.H.; Hu, G. Female early adult depression results in detrimental impacts on the behavioral performance and brain development in offspring. CNS Neurosci. Ther. 2012, 18, 461-470. [CrossRef]

221. Banasr, M.; Duman, R.S. Glial loss in the prefrontal cortex is sufficient to induce depressive-like behaviors. Biol. Psychiatry 2008, 64, 863-870. [CrossRef]

222. Fullana, M.N.; Ruiz-Bronchal, E.; Ferrés-Coy, A.; Juárez-Escoto, E.; Artigas, F.; Bortolozzi, A. Regionally selective knockdown of astroglial glutamate transporters in infralimbic cortex induces a depressive phenotype in mice. Glia 2019, 67, 1122-1137. [CrossRef]

223. Fava, M. Diagnosis and definition of treatment-resistant depression. Biol. Psychiatry 2003, 53, 649-659. [CrossRef]

224. Ionescu, D.F.; Rosenbaum, J.F.; Alpert, J.E. Pharmacological approaches to the challenge of treatment-resistant depression. Dialogues Clin. Neurosci. 2015, 17, 111-126. [PubMed]

225. Gaynes, B.N.; Lux, L.; Gartlehner, G.; Asher, G.; Forman-Hoffman, V.; Green, J.; Boland, E.; Weber, R.P.; Randolph, C.; Bann, C.; et al. Defining treatment-resistant depression. Depress. Anxiety 2020, 37, 134-145. [CrossRef]

226. Trullas, R.; Skolnick, P. Functional antagonists at the NMDA receptor complex exhibit antidepressant actions. Eur. J. Pharmacol. 1990, 185, 1-10. [CrossRef]

227. DiazGranados, N.; Ibrahim, L.A.; Brutsche, N.E.; Ameli, R.; Henter, I.D.; Luckenbaugh, D.A.; Machado-Vieira, R.; Zarate, C.A., Jr. Rapid resolution of suicidal ideation after a single infusion of 
an N-methyl-D-aspartate antagonist in patients with treatment-resistant major depressive disorder. J. Clin. Psychiatry 2010, 71, 1605-1611. [CrossRef]

228. Singh, J.B.; Fedgchin, M.; Daly, E.J.; De Boer, P.; Cooper, K.; Lim, P.; Pinter, C.; Murrough, J.W.; Sanacora, G.; Shelton, R.C.; et al. A double-blind, randomized, placebo-controlled, dose-frequency study of intravenous ketamine in patients with treatment-resistant depression. Am. J. Psychiatry 2016, 173, 816-826. [CrossRef]

229. Maeng, S.; Zarate, C.A.J.; Du, J.; Schloesser, R.J.; McCammon, J.; Chen, G.; Manji, H.K. Cellular mechanisms underlying the antidepressant effects of ketamine: Role of $\alpha$-amino-3-hydroxy-5-methylisoxazole-4-propionic acid receptors. Biol. Psychiatry 2008, 63, 349-352. [CrossRef]

230. Autry, A.E.; Adachi, M.; Nosyreva, E.; Na, E.S.; Los, M.F.; Cheng, P.F.; Kavalali, E.T.; Monteggia, L.M. NMDA receptor blockade at rest triggers rapid behavioural antidepressant responses. Nature 2011, 475, 91-95. [CrossRef]

231. Koike, H.; Iijima, M.; Chaki, S. Involvement of AMPA receptor in both the rapid and sustained antidepressant-like effects of ketamine in animal models of depression. Behav. Brain Res. 2011, 224, 107-111. [CrossRef]

232. Li, N.; Lee, B.; Liu, R.J.; Banasr, M.; Dwyer, J.M.; Iwata, M.; Li, X.Y.; Aghajanian, G.; Duman, R.S. mTOR-dependent synapse formation underlies the rapid antidepressant effects of NMDA antagonists. Science 2010, 329, 959-964. [CrossRef]

233. Hashimoto, K. Role of the mTOR signaling pathway in the rapid antidepressant action of ketamine. Expert Rev. Neurother. 2011, 11, 33-36. [CrossRef]

234. Koike, H.; Chaki, S. Requirement of AMPA receptor stimulation for the sustained antidepressant activity of ketamine and LY341495 during the forced swim test in rats. Behav. Brain Res. 2014, 271, 111-115. [CrossRef] [PubMed]

235. Zhang, K.; Yamaki, V.N.; Wei, Z.; Zheng, Y.; Cai, X. Differential regulation of GluA1 expression by ketamine and memantine. Behav. Brain Res. 2017, 316, 152-159. [CrossRef] [PubMed]

236. Duman, R.S.; Shinohara, R.; Fogaça, M.V.; Hare, B. Neurobiology of rapid-acting antidepressants: Convergent effects on GluA1-synaptic function. Mol. Psychiatry 2019, 24, 1816-1832. [CrossRef] [PubMed]

237. Klann, E.; Antion, M.D.; Banko, J.L.; Hou, L. Synaptic plasticity and translation initiation. Learn. Mem. 2004, 11, 365-372. [CrossRef]

238. Abe, N.; Borson, S.H.; Gambello, M.J.; Wang, F.; Cavalli, V. Mammalian target of rapamycin (mTOR) activation increases axonal growth capacity of injured peripheral nerves. J. Biol. Chem. 2010, 285, 28034-28043. [CrossRef]

239. Jernigan, C.S.; Goswami, D.B.; Austin, M.C.; Iyo, A.H.; Chandran, A.; Stockmeier, C.A.; Karolewicz, B. The mTOR signaling pathway in the prefrontal cortex is compromised in major depressive disorder. Prog. Neuropsychopharmacol. Biol. Psychiatry 2011, 35, 774-1779. [CrossRef]

240. Chandran, A.; Iyo, A.H.; Jernigan, C.S.; Legutko, B.; Austin, M.C.; Karolewicz, B. Reduced phosphorylation of the mTOR signaling pathway components in the amygdala of rats exposed to chronic stress. Prog. Neuropsychopharmacol. Biol. Psychiatry 2012, 40, 240-245. [CrossRef]

241. Fang, Z.H.; Lee, C.H.; Seo, M.K.; Cho, H.; Lee, J.G.; Lee, B.J.; Park, S.W.; Kim, Y.H. Effect of treadmill exercise on the BDNF-mediated pathway in the hippocampus of stressed rats. Neurosci. Res. 2013, 76, 187-194. [CrossRef]

242. Zhong, P.; Wang, W.; Pan, B.; Liu, X.; Zhang, Z.; Long, J.Z.; Zhang, H.T.; Cravatt, B.F.; Liu, Q.S. Monoacylglycerol lipase inhibition blocks chronic stress-induced depressive-like behaviors via activation of mTOR signaling. Neuropsychopharmacology 2014, 39, 1763-1776. [CrossRef]

243. Fuchikami, M.; Thomas, A.; Liu, R.; Wohleb, E.S.; Land, B.B.; DiLeone, R.J.; Aghajanian, G.K.; Duman, R.S. Optogenetic stimulation of infralimbic PFC reproduces ketamine's rapid and sustained antidepressant actions. Proc. Natl. Acad. Sci. USA 2015, 112, 8106-8111. [CrossRef] [PubMed]

244. Fukumoto, K.; Iijima, M.; Chaki, S. The antidepressant effects of an mGlu2/3 receptor antagonist and ketamine require AMPA receptor stimulation in the $\mathrm{MPFC}$ and subsequent activation of the 5-HT neurons in the DRN. Neuropsychopharmacology 2016, 41, 1046-1056. [CrossRef]

245. Covington, H.E., III; Lobo, M.K.; Maze, I.; Vialou, V.; Hyman, J.M.; Zaman, S.; LaPlant, Q.; Mouzon, E.; Ghose, S.; Tamminga, C.A.; et al. Antidepressant effect of optogenetic stimulation of the medial prefrontal cortex. J. Neurosci. 2010, 30, 16082-16090. [CrossRef] 
246. Warden, M.R.; Selimbeyoglu, A.; Mirzabekov, J.J.; Lo, M.; Thompson, K.R.; Kim, S.Y.; Adhikari, A.; Tye, K.M.; Frank, L.M.; Deisseroth, K. A prefrontal cortex-brainstem neuronal projection that controls response to behavioural challenge. Nature 2012, 492, 428-432. [CrossRef] [PubMed]

247. Challis, C.; Beck, S.G.; Berton, O. Optogenetic modulation of descending prefrontocortical inputs to the dorsal raphe bidirectionally bias socioaffective choices after social defeat. Front. Behav. Neurosci. 2014, 8, 43. [CrossRef]

248. Liu, Y.; Zhao, J.; Guo, W. Emotional roles of mono-aminergic neurotransmitters in major depressive disorder and anxiety disorders. Front. Psychol. 2018, 9, 2201. [CrossRef] [PubMed]

249. Lucki, I.; Singh, A.; Kreiss, D.S. Antidepressant-like behavioral effects of serotonin receptor agonists. Neurosci. Biobehav. Rev. 1994, 18, 85-95. [CrossRef]

250. Mccauley, E.; Carlson, G.A.; Calderon, R. The role of somatic complaints in the diagnosis of depression in children and adolescents. J. Am. Acad. Child Adolesc. Psychiatry 1991, 30, 631-635. [CrossRef] [PubMed]

251. Gerber, P.D.; Barrett, J.E.; Barrett, J.A.; Oxman, T.E.; Manheimer, E.; Smith, R.; Whiting, R.D. The relationship of presenting physical complaints to depressive symptoms in primary care patients. J. Gen. Intern. Med. 1992, 7, 170-173. [CrossRef] [PubMed]

252. Liu, Y.; Zhao, J.; Fan, X.; Guo, W. Dysfunction in serotonergic and noradrenergic systems and somatic symptoms in psychiatric disorders. Front. Psychiatry 2019, 10, 286. [CrossRef] [PubMed]

253. Fava, M. The role of the serotonergic and noradrenergic neurotransmitter systems in the treatment of psychological and physical symptoms of depression. J. Clin. Psychiatry 2003, 64, 26-29. [PubMed]

254. Stahl, S.M. The psychopharmacology of painful physical symptoms in depression. J. Clin. Psychiatry. 2002, 63, 382-383. [CrossRef] [PubMed]

255. Ruhé, H.G.; Mason, N.S.; Schene, A.H. Mood is indirectly related to serotonin, norepinephrine and dopamine levels in humans: A meta-analysis of monoamine depletion studies. Mol. Psychiatry 2007, 12, 331-359. [CrossRef] [PubMed]

256. Shopsin, B.; Gershon, S.; Goldstein, M.; Friedman, E.; Wilk, S. Use of synthesis inhibitors in defining a role for biogenic amines during imipramine treatment in depressed patients. Psychopharmacol. Commun. 1975, 1, 239-249. [PubMed]

257. Shopsin, B.; Friedman, E.; Gershon, S. Parachlorophenylalanine reversal of tranylcypromine effects in depressed patients. Arch. Gen. Psychiatry 1976, 33, 811-819. [CrossRef]

258. Domino, E.F. Taming the ketamine tiger. Anesthesiology 2010, 113, 678-684. [CrossRef]

259. Muller, J.; Pentyala, S.; Dilger, J.; Pentyala, S. Ketamine enantiomers in the rapid and sustained antidepressant effects. Ther. Adv. Psychopharmacol. 2016, 6, 185-192. [CrossRef]

260. Zhang, J.C.; Li, S.X.; Hashimoto, K. R (-)-ketamine shows greater potency and longer lasting antidepressant effects than S (+)-ketamine. Pharmacol. Biochem. Behav. 2014, 116, 137-141. [CrossRef]

261. Hashimoto, K. The R-stereoisomer of ketamine as an alternative for ketamine for treatment-resistant major depression. Clin. Psychopharmacol. Neurosci. 2014, 12, 72-73. [CrossRef]

262. Yang, C.; Shirayama, Y.; Zhang, J.C.; Ren, Q.; Yao, W.; Ma, M.; Dong, C.; Hashimoto, K. R-ketamine: A rapid-onset and sustained antidepressant without psychotomimetic side effects. Transl. Psychiatry 2015, 5, e632. [CrossRef]

263. Fukumoto, K.; Toki, H.; Iijima, M.; Hashihayata, T.; Yamaguchi, J.I.; Hashimoto, K.; Chaki, S. Antidepressant potential of $(R)$-ketamine in rodent models: Comparison with (S)-ketamine. J. Pharmacol. Exp. Ther. 2017, 361, 9-16. [CrossRef] [PubMed]

264. Leal, G.C.; Bandeira, I.D.; Correia-Melo, F.S.; Telles, M.; Mello, R.P.; Vieira, F.; Lima, C.S.; Jesus-Nunes, A.P.; Guerreiro-Costa, L.N.F.; Marback, R.F.; et al. Intravenous arketamine for treatment-resistant depression: Open-label pilot study. Eur. Arch. Psychiatry Clin. Neurosci. 2020. [CrossRef] [PubMed]

265. Preskorn, S.H.; Baker, B.; Kolluri, S.; Menniti, F.S.; Krams, M.; Landen, J.W. An innovative design to establish proof of concept of the antidepressant effects of the NR2B subunit selective N-methyl-D-aspartate antagonist, CP-101, 606, in patients with treatment refractory major depressive disorder. J. Clin. Psychopharmacol. 2008, 28, 631-637. [CrossRef] [PubMed]

266. Ibrahim, L.; Diaz Granados, N.; Jolkovsky, L.; Brutsche, N.; Luckenbaugh, D.A.; Herring, W.J.; Potter, W.Z.; Zarate, C.A.J. A randomized, placebo-controlled, crossover pilot trial of the oral selective NR2B antagonist MK-0657 in patients with treatment-resistant major depressive disorder. J. Clin. Psychopharmacol. 2012, 32, 551-557. [CrossRef] 
267. Burgdorf, J.; Zhang, X.L.; Nicholson, K.L.; Balster, R.L.; Leander, J.D.; Stanton, P.K.; Gross, A.L.; Kroes, R.A.; Moskal, J.R. GLYX-13, a NMDA receptor glycine-site functional partial agonist, induces antidepressant-like effects without ketamine-like side effects. Neuropsychopharmacology 2013, 38, 729-742. [CrossRef]

268. Sanacora, G.; Smith, M.A.; Pathak, S.; Su, H.L.; Boeijinga, P.H.; McCarthy, D.J.; Quirk, M.C. Lanicemine: A low-trapping NMDA channel blocker produces sustained antidepressant efficacy with minimal psychotomimetic adverse effects. Mol. Psychiatry 2014, 19, 978-985. [CrossRef]

269. Zarate, C.A.J.; Mathews, D.; Ibrahim, L.; Chaves, J.F.; Marquardt, C.; Ukoh, I.; Jolkovsky, L.; Brutsche, N.E.; Smith, M.A.; Luckenbaugh, D.A. A randomized trial of a low-trapping nonselective N-methyl-D-aspartate channel blocker in major depression. Biol. Psychiatry 2013, 74, 257-264. [CrossRef]

270. Auberson, Y.P.; Allgeier, H.; Bischoff, S.; Lingenhoehl, K.; Moretti, R.; Schmutz, M. 5-Phosphonomethylquinoxalinediones as competitive NMDA receptor antagonists with a preference for the human $1 \mathrm{~A} / 2 \mathrm{~A}$, rather than $1 \mathrm{~A} / 2 \mathrm{~B}$ receptor composition. Bioorg. Med. Chem. Lett. 2002, 12, 1099-1102. [CrossRef]

271. Neyton, J.; Paoletti, P. Relating NMDA receptor function to receptor subunit composition: Limitations of the pharmacological approach. J. Neurosci. 2006, 36, 1331-1333. [CrossRef]

272. Fischer, G.; Mutel, V.; Trube, G.; Malherbe, P.; Kew, J.N.; Mohacsi, E.; Heitz, M.P.; Kemp, J.A. Ro 25-6981, a highly potent and selective blocker of N-methyl-D-aspartate receptors containing the NR2B subunit. Characterization in vitro. J. Pharmacol. Exp. Ther. 1997, 283, 1285-1292.

273. Jiménez-Sánchez, L.; Campa, L.; Auberson, Y.P.; Adell, A. The role of GluN2A and GluN2B subunits on the effects of NMDA receptor antagonists in modeling schizophrenia and treating refractory depression. Neuropsychopharmacology 2014, 39, 2673-2680. [CrossRef] [PubMed]

274. Ide, S.; Ikekubo, Y.; Mishina, M.; Hashimoto, K.; Ikeda, K. Role of NMDA receptor GluN2D subunit in the antidepressant effects of enantiomers of ketamine. J. Pharmacol. Sci. 2017, 135, 138-140. [CrossRef] [PubMed]

275. Ide, S.; Ikekubo, Y.; Mishina, M.; Hashimoto, K.; Ikeda, K. Cognitive impairment that is induced by $(R)$-ketamine is abolished in NMDA GluN2D receptor subunit knockout mice. Int. J. Neuropsychopharmacol. 2019, 22, 449-452. [CrossRef] [PubMed]

276. Dawson, L.A.; Li, P. Effects of 5-HT (6) receptor blockade on the neurochemical outcome of antidepressant treatment in the frontal cortex of the rat. J. Neural Transm. (Vienna) 2003, 110, 577-590. [CrossRef]

277. Gören, M.Z.; Küçükibrahimoglu, E.; Berkman, K.; Terzioglu, B. Fluoxetine partly exerts its actions through GABA: A neurochemical evidence. Neurochem. Res. 2007, 32, 1559-1565. [CrossRef]

278. Murray, J.D.; Anticevic, A.; Gancsos, M.; Ichinose, M.; Corlett, P.R.; Krystal, J.H.; Wang, X.-J. Linking microcircuit dysfunction to cognitive impairment: Effects of disinhibition associated with schizophrenia in a cortical working memory model. Cereb. Cortex 2014, 24, 859-872. [CrossRef]

279. Gerhard, D.M.; Pothula, S.; Liu, R.J.; Wu, M.; Li, X.Y.; Girgenti, M.J.; Taylor, S.R.; Duman, C.H.; Delpire, E.; Picciotto, M.; et al. GABA interneurons are the cellular trigger for ketamine's rapid antidepressant actions. J. Clin. Invest. 2020, 130, 1336-1349. [CrossRef] [PubMed]

280. Miller, O.H.; Yang, L.; Wang, C.C.; Hargroder, E.A.; Zhang, Y.; Delpire, E.; Hall, B.J. GluN2B-containing NMDA receptors regulate depression-like behavior and are critical for the rapid antidepressant actions of ketamine. Elife 2014, 3, e03581. [CrossRef] [PubMed]

281. López-Gil, X.; Babot, Z.; Amargós-Bosch, M.; Suñol, C.; Artigas, F.; Adell, A. Clozapine and haloperidol differently suppress the MK-801-increased glutamatergic and serotonergic transmission in the medial prefrontal cortex of the rat. Neuropsychopharmacology 2007, 32, 2087-2097. [CrossRef] [PubMed]

282. Akinfiresoye, L.; Tizabi, Y. Antidepressant effects of AMPA and ketamine combination: Role of hippocampal BDNF, synapsin, and mTOR. Psychopharmacology (Berl) 2013, 230, 291-298. [CrossRef] [PubMed]

(C) 2020 by the author. Licensee MDPI, Basel, Switzerland. This article is an open access article distributed under the terms and conditions of the Creative Commons Attribution (CC BY) license (http://creativecommons.org/licenses/by/4.0/). 